\title{
www.mdbd.usm.my
}

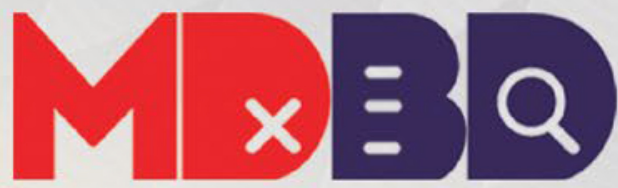

Third International Conference on

MOLECULAR DIAGNOSTICS

BIOMARKER \&DISCOVERY

2018

Recent Insights in Cancer From Biodiscovery to Translational Outcomes

24 - 25 September 2018

Eureka Complex USM Penang, Malaysia
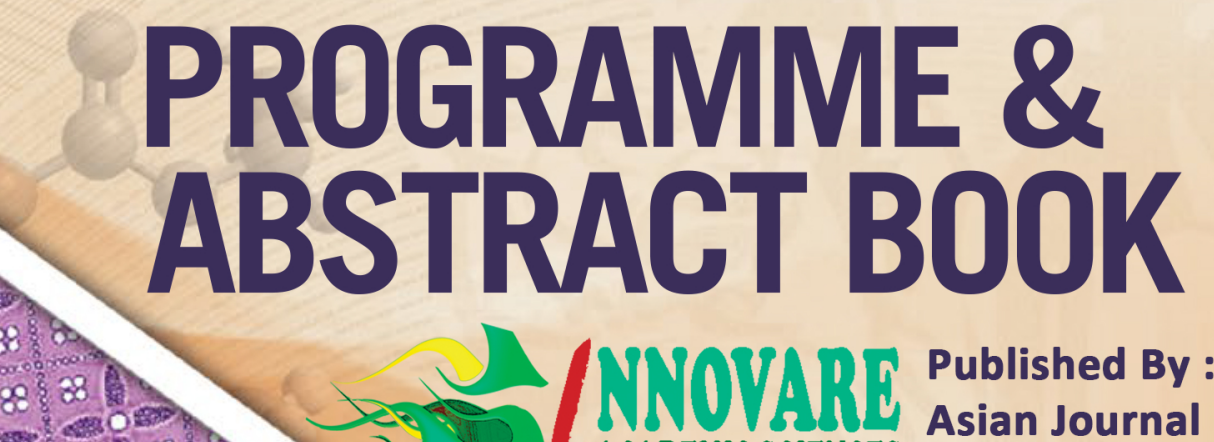

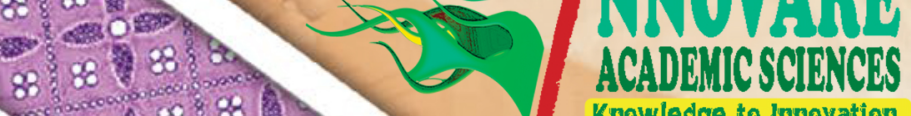

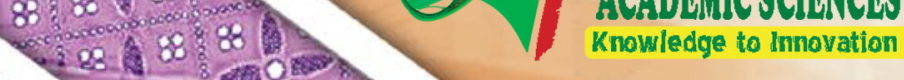

Asian Journal of Pharmaceutical \& Clinical Research www.ajpcr.com 


\section{Word of Welcome}

Greetings and a warm welcome to the $3^{\text {rd }}$ International Conference on Molecular Diagnostics \& Biomarker Discovery (MDBD 2018) in Penang!

Cancer is a major global health concern and its burden will rise in the near future due to a growing, aging world population. In tandem, the scientific study of cancer is advancing rapidly. A deeper understanding of cancer will lead to improved prevention strategies, diagnostics, therapeutics and better care for cancer patients. The conference theme "Recent insights in cancer, from biodiscovery to translational outcomes" reflects the span of cancer research to tackle these issues.

MDBD 2018 is the $3^{\text {rd }}$ such conference organised by INFORMM, following its inaugural event in 2013, and the $2^{\text {nd }}$ in 2017. This year, the conference has taken another step in bridging INFORMM, and Curtin Health Innovation Research Institute (CHIRI), Curtin University, in the field of cancer research.

We seek to assemble researchers and leaders from the region to share their experience and progress made in diverse fields from cancer biology and immunology to biodiscovery, diagnostics and therapeutics.

We are delighted to offer a comprehensive programme of world-leading plenary speakers, early career researchers, academic and industrial experts, as well as many informative presentations, posters and exhibition booths. The conference aims to encourage effective knowledge sharing, networking and socializing.

Despite the busy schedule, we hope you will be able to enjoy Penang, also known as Pearl of the Orient. A fascinating fusion of the East and West, Penang embraces modernity while retaining its traditions and old world charm. These are reflected in its harmonious multiracial populace and well-preserved heritage buildings which led to George Town being accorded a UNESCO World Cultural Heritage Site in 2008. Long regarded as the food capital of Malaysia, Penang also entices visitors with its beautiful coasts and scrumptious cuisines.

We look forward to personally welcoming you in Penang!

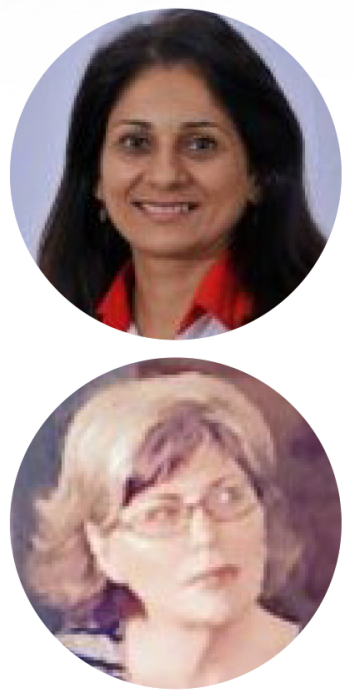

Prof. Dr. Gurjeet Kaur Conference Chair

Assoc. Prof. Delia Nelson

Conference Co-Chair

0

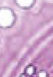
D. 88

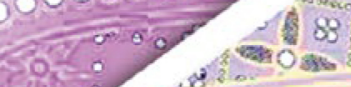

Conference Chair 


\title{
Organising Committee, 3rd MDBD 2018, 24-25 Sept 2018
}

\author{
Chair \\ Gurjeet Kaur
}

\author{
Advisors \\ Professor Rahmah Noordin, PhD, FASc, Director, INFORMM, Universiti Sains Malaysia \\ Prof. Michael Berndt, \\ Curtin Distinguished Professor, Pro Vice-Chancellor \\ Faculty of Health Sciences, Curtin University
}

\section{Secretary \\ Daruliza Kernain \\ Chew Ai Lan}

\section{Treasurer}

S. Sasidharan

Azlina Omar

\section{Scientific}

Oon Chern Ein

Norsyahida Arifin

Khairul Mohd Fadzli Mustaffa

S. Sasidharan

Eugene Ong Boon Beng

Ayappa Subramaniam

Lee Yuean Ting

Tan Yi Jer

\section{Secretariat and Registration}

Noor Fatmawati Mokhtar Nor Dyana Zakaria Azimah

Ahmad

Nurul' Jannah Binti Kamaruz'zaman

Mazni Binti Rosli

\author{
Sponsorship \\ Khoo Boon Yin \\ Ong Ming Thong \\ Muhammad Noor Fais bin Kamarudin \\ Sabariah Osman
}

\section{Publicity \& Design}

Lai Ngit Shin Nurulhasanah Othman Choong Yee Siew Nurul' Jannah Binti Kamaruz'zaman

Mazni Binti Rosli

\author{
Hospitality \& Technical \\ Venugopal Balakrishnan \\ Leow Chiuan Herng \\ Tye Gee Jun \\ Muhammad Hafiznur \\ Ahmad Anas Hamka Ayob \\ Adli Akbar Bin Hamzah \\ Mohd Azizi Bin Ahmat \\ Muhamad Nazri Mahamad Isa

\section{Protocol} \\ Chew Ai Lan \\ Mohd. Redzuan bin Asmi \\ Sabariah Osman \\ Noorizan Mizwan
}




\section{PROGRAM SCHEDULE}

\section{Sept. 2018 Day 1 (Monday)}

0800-0900: Registration

WELCOME ADDRESS \& OPENING CEREMONY

Assoc. Prof Dr. Aziah Ismail (INFORMM, USM) and

0900-0930: $\quad$ Prof. Michael Berndt (Curtin University)

Y. Bhg. Prof Mohd Nazalan Mohd Najimudin

Director Nexus, USM

0930-1030: $\quad$ Marco Falasca, Curtin University

- "Exosomes in pancreatic cancer diagnosis and therapy"

1030-1100:

Tea Break, Poster Viewing, Exhibition

\section{SYMPOSIUM 1 - Cancer Therapeutics}

Teo Soo-Hwang, Cancer Research Malaysia (11.00am-11.30am)

-"Precision medicine in breast cancer in Asians: from predisposition to treatment choices"

1100-1305: John E Connolly, Tessa Therapeutics Pte Ltd (11.30am-12.00 noon)

- "Virus Specific T cells as platform for Solid Tumor Immunotherapy"

Crispin Dass, Curtin University (12.00 noon-12.30pm)

- "PEDF, cancer and bone"

Teh Boon Eng (12.30 pm-12.50pm)

- "Dissecting cancer heterogeneity with mass cytometry"

1305-1400: $\quad$ Lunch Break, Exhibition, Poster Viewing

SYMPOSIUM 2 - Cancer Biology/Immunology

Delia Nelson, Curtin University $(2.00 \mathrm{pm}-2.30 \mathrm{pm})$

- "Cancer, chemo-immunotherapy and the ageing immune system"

Vincenzo DeLaurenzi, University “G. d'Annunzio” Chieti-Pescara (2.30pm-3.00pm)

1400-1545:

- "New therapeutic approaches to pancreatic cancer"

Connie Jackaman, Curtin University $(3.00 \mathrm{pm}-3.30 \mathrm{pm})$

- "Aging and cancer: Macrophage dysregulation during aging and the impact on cancer immunotherapy in the elderly"

Q\&A (3.30pm-3.45pm)

1545-1600: $\quad$ Tea Break, Exhibition, Poster Viewing

1600-1730: $\quad$ FREE PAPERS SESSION 1

1730: $\quad$ End of Programme 
25 Sept. 2018 Day 2 (Tuesday)

Ramanuj Dasgupta, A*STAR

-"Mapping trajectories of drug-induced tumor evolution "one cell at-a-time"

1000-1030 Tea Break, Exhibition, Poster Viewing

$1030-1215$

$1215-1300$

FREE PAPERS SESSION 2

$1300-1400$

Lunch Break, Exhibition, Poster Viewing

\section{SYMPOSIUM 4 - Cancer Biology/ Biodiscovery}

Venugopal Balakrishnan, Universiti Sains Malaysia $(2.00 \mathrm{pm}-2.30 \mathrm{pm})$

- "Dysregulation of c-myc gene by HPV oncoproteins for continuous cell proliferation in cervical cancer"

Deirdre Coombe, Curtin University (2.30pm-3.00pm)

$1400-1515$

- "Understanding cell-matrix interactions in vitro: Microscopy is an indispensable tool"

Q\&A (3.00pm-3.15pm)

1515-1545 Tea Break, Exhibition, Poster Viewing

1545-1700 FREE PAPERS SESSION 3

CLOSING CEREMONY

Prize Presentation to best poster and oral presenters

$1700-1730$

Closing remarks

\section{End of Conference}




\section{INDEX}

\section{ORAL PRESENTATION}

OP-01 2-METHOXY-1,4-NAPHTHOQUINONE (MNQ) INHIBITS GLYCOLYTIC ACTIVITIES IN BREAST CANCER CELL LINE (MDA-MB-231)

OP-02 ASSOCIATION OF CYTOKINE LEVELS IN FEMALE WITH AUTOANTIBODIES ANTI-SSA/RO AND/OR ANTI-SSB/LA OF NORTHERN MALAYSIA

OP-03 LEPTIN ADMINISTRATION INDUCES THE EXPRESSION OF TUMORIGENIC GENES IN THE STOMACH OF MALE SPRAGUE-DAWLEY RATS

OP-04 FUNCTIONAL ROLE OF FRINGE IN TUMOR ANGIOGENESIS

OP-05 INVERTEBRATES LIVING IN POLLUTED ENVIRONMENTS ARE A POTENTIAL SOURCE OF NOVEL ANTITUMOR MOLECULE(S)

OP-06 GUT MICROBES OF INVERTEBRATES LIVING IN POLLUTED ENVIRONMENTS ARE POTENTIAL SOURCE OF NOVEL ANTICANCER AGENTS

OP-07 ASSOCIATION OF SALTED FISH CONSUMPTION WITH NASOPHARYNGEAL CANCER RISK IN ASIAN POPULATIONS: A SYSTEMATIC REVIEW AND META-ANALYSIS

OP-08

OP-09

OP-10 EXPRESSION OF E-CADHERIN IN ORAL POTENTIAL MALIGNANT DISORDERS AND ORAL CANCERS BIOMARKER DISCOVERY ON MICROARRAY DATA USING INTEGRATED ASSOCIATIVE CLASSIFICATION TIGERNUT (CYPERUS ESCULENTUS) EXTRACTS INDUCE A DIFFERENT TYPE OF CELL CYCLE ARREST IN MDA-MB231 AND MCF7

OP-11 CELLULAR CHARACTERIZATION AND TRANSCRIPTOME ANALYSIS FOR IDENTIFICATION OF BIOMARKERS FOR CISPLATIN-RESISTANT BREAST CANCER STEM CELLS

OP-12 GENOTOXICITY OF DIALYSED C-SERUM PRECIPITATE (DCP) OF HEVEA BRASILIENSIS PRECLINICAL TOXICOLOGY AND CLASTOGENICITY STUDY OF A NOVEL SIRTUIN INHIBITOR IN VIVO EXPRESSION OF CIRCULATING MIR-101 AND MIR-744 IN NASOPHARYNGEAL CARCINOMA AND THEIR PERFORMANCE AS DIAGNOSTIC BIOMARKERS

OP-15 IMMUNOHISTOCHEMICAL EXPRESSION OF IGFBP-2 PROTEIN IN NORMAL CERVIX, CERVICAL INTRAEPITHELIAL NEOPLASIA AND SQUAMOUS CELL CARCINOMA OF THE CERVIX

OP-16 EVALUATION OF MOLECULAR CHANGES OF GENES INVOLVED IN CELL CYCLE AND APOPTOSIS IN RELATION TO CERVICAL CARCINOGENESIS

OP-17 CORRELATION OF LEPTIN WITH CLINICO-PATHOLOGICAL FEATURES OF BREAST CANCER

OP-18 METHADONE HYDROCHLORIDE INDUCED APOPTOSIS ON LEUKAEMIA CELL LINES

OP-19 A NOVEL SIRTUIN INHIBITOR (BZD9L1) AS AN ADJUNCT TO CHEMOTHERAPY IN COLORECTAL CANCER

OP-20 THE EFFECTS OF TETRODOTOXIN ON GROWTH AND EXPRESSION OF NNAV1.5 IN BREAST CANCER CELLS

OP-21 CHROMOGENIC IN SITU HYBRIDISATION ANALYSIS REVEALED ELEVATED TRNAIMET EXPRESSION IN TUMOUR VERSUS NORMAL TISSUES

OP-22 ANTIVIRAL ACTIVITY AGAINST DENGUE VIRUS BY FUSARIUM PROLIFERATUM OPT5 PREPARATION AND CHARACTERIZATION OF 1,4,7-TRIAZACYCLONONANE,1-GLUTARIC ACID-4,7-

OP-23 ACETIC ACID (NODAGA)-PAMIDRONIC ACID (NOD-PAM) PRECURSOR FOR GALLIUM-68 PET BONE SCAN

\section{POSTER PRESENTATION}

PP-01

RUNX1 AND CRLF2 GENES AMPLIFICATION IN A HIGH HYPERDIPLOID CHILDHOOD ACUTE LYMPHOBLASTIC LEUKAEMIA PATIENT

IDENTIFICATION OF COPY NUMBER ALTERATIONS (CNAS) IN PAEDIATRIC B-CELL ACUTE

PP-02 LYMPHOBLASTIC LEUKEMIA (B-ALL) USING MULTIPLEX LIGATION-DEPENDENT PROBE 25 AMPLIFICATION (MLPA):A PRELIMINARY STUDY

PP-03 BZD9L1: ELUCIDATION OF ITS ANTI-ANGIOGENIC POTENTIAL IN COLORECTAL CANCER ASSESSMENT OF TRPV4 ION CHANNEL AND ITS ROLE IN COLORECTAL CANCER

PP-04 CELLS

VANCOMYCIN REDUCED SUSCEPTIBILITY TO METHICILLIN-RESISTANT-

PP-05 STAPHYLOCOCCUS AUREUS

EVALUATION ON THE QUALITY OF GENOMIC DNA IN BOTH SALIVA AND WHOLE BLOOD AS SOURCE OF DNA AND ITS UTILISATION IN TETRA-ARMS PCR EFFECT OF ASTAXANTHIN-RICH XANTHOPHYLLOMYCES DENDRORHOUS EXTRACT

PP-07 ON THE CELL CYCLE OF BREAST CANCER CELLS 
DOWNREGULATION OF MMP-9

PP-09 UP-REGULATION OF VIMENTIN PROTEIN EXPRESSION IN TZD SOLUTIONS

PRETREATED BONE MARROW-DERIVED MESENCHYMAL STEM CELLS

PP-10

ANTI-CANCER PROPERTY OF RILUZOLE ON OESTROGEN POSITIVE BREAST CANCER

CELLS

INVESTIGATING THE PHENOTYPICAL GROWTH AND INVASION OF THE THREE-

PP-11 DIMENSIONAL (3D) SPHEROIDS GENERATED FROM SIHA, ME180, HT3 AND C33-A CERVICAL CANCER CELL LINES

PP-12 GREATER MRNA EXPRESSION OF ANTIGEN PROCESSING MACHINERY (APM) IN AGGRESSIVE HUMAN BREAST CANCER CELLS

A SYSTEMATIC REVIEW ON NANO-TIO2 PHYSIOCHEMICAL PROPERTIES TARGETED AS CANCER THERAPEUTIC AGENTS

THE ANTIOXIDATIVE STRESS CAPACITY OF APOCYNIN AND CATALASE ON

PP-14 BIOCHEMICAL, RENAL HAEMODYNAMIC AND HISTOPATHOLOGICAL STUDIES IN LARGININE INDUCED HYPOTENSION MODEL: THE ROLE OF OXIDATIVE STRESS 


\title{
2-METHOXY-1,4-NAPHTHOQUINONE (MNQ) INHIBITS GLYCOLYTIC ACTIVITIES IN BREAST CANCER CELL LINE (MDA-MB-231)
}

\author{
MAT DAUD, SYUKRIYAH ${ }^{1}$; YAACOB; NIK SORIANI ${ }^{2}$; MUSTAFA, MOHD ZULKIFLI ${ }^{3}$; FAUZI, AGUSTINE NENGSIH ${ }^{4}$
}

1,2,4 Department of Chemical Pathology, School of Medical Sciences, Universiti Sains Malaysia, 16150, Kubang Kerian Kelantan Malaysia. ${ }^{3}$ Department of Neurosciences, School of Medical Sciences, Universiti Sains Malaysia, 16150 Kubang Kerian, Kelantan, Malaysia. Email: syukriyah@student.usm.my

\begin{abstract}
2-Methoxyl-1,4-Naphthoquinone (MNQ) is one of the quinones that can be extracted from garden balsam (Impatiens balsamina). MNQ was reported to induce apoptosis, increase DNA damage by reactive oxygen species (ROS) production and suppress the cells' invasion and migration in several cancer cell lines, including highly metastatic breast cancer cells MDA-MB-231. It is known that cancer cells exhibit high levels of glycolysis as well as lactate production which may contribute to metastatic activity. This study was conducted to investigate the effect of MNQ on glycolytic activities in MDA-MB-231 cells. Initially, the cells were tested with various doses of MNQ (5-100 $\mu \mathrm{M})$ for MTT proliferation assay. When the half maximal inhibitory concentration ( $\mathrm{IC}_{50}$ ) was obtained, the cells were tested with $\mathrm{IC}_{50}$ dose of MNQ for glucose uptake and lactate assays. The results showed, MNQ decreased the percentage of MDA-MB-231 cell viability in a dose-dependent manner with IC $\mathrm{I}_{50}$ value of $29 \mu \mathrm{M} / \mathrm{ml}$. The percentage of glucose uptake into the cells and lactate production decreased significantly after treating with the MNQ as compared to untreated controls. Our findings indicated the ability of MNQ to inhibit the glycolytic activities in MDA-MB-231 cells, suggested the potential of MNQ to be further developed as an effective agent/adjuvant against highly metastatic breast cancer.
\end{abstract}

Keywords: 2-Methoxy-1,4-Naphthoquinone (MNQ); Glucose metabolism; Glycolytic activity; Breast cancer cells; MDA-MB-231 cells 


\title{
ASSOCIATION OF CYTOKINE LEVELS IN FEMALE WITH AUTOANTIBODIES ANTI-SSA/RO AND/OR ANTI-SSB/LA OF NORTHERN MALAYSIA
}

\author{
ABDUL ZUBIR, ANISAH ${ }^{1,2}$; BAHARUDIN, BALQISSIAH ${ }^{2}$; HUSAIN, NOOR SHUHAILA3 ${ }^{3}$ SYAZULI ZULKAFLI, NOR \\ EFFA $^{1}$
}

${ }^{1}$ Regenerative Medicine Cluster, Advanced Medical and Dental Institute, Universiti Sains Malaysia, 13200 Kepala Batas, Pulau Pinang, Malaysia. ${ }^{2}$ Microbiology Unit, Pathology Department, Hospital Tuanku Fauziah, 01000 Kangar, Perlis, Malaysia. ${ }^{3}$ Inventory and Component Unit, North Regional Blood Centre, Hospital Sultanah Bahiyah II,05100 Alor Setar, Kedah, Malaysia. Email: anisahzubir@student.usm.my

\begin{abstract}
Connective tissue diseases are one of the common autoimmune diseases in developed countries and always associated with high levels of autoantibody anti-SSA/Ro and anti-SSB/La. The current study was conducted to determine the association of IL-6 \& IL-10 sera levels in female positive anti-SSA/Ro or anti-SSB/La or both in Northern Malaysia. Samples were collected from government hospitals and were screened for Connective tissue disease (CTD) using enzyme immunoassay (EIA). Presence of anti-nuclear antibody (ANA) patterns was tested by indirect immunofluorescence assay (IFA). Speckled IFA pattern was tested for anti-SSA/Ro and anti-SSB/La by EIA. Levels of IL-6 and IL-10 were measured using ELISA. Our findings showed that the mean age of positive anti-SSA/Ro or anti-SSB/La in Female of Northern Malaysia was 37.9 years (SD \pm 14.99$)(\mathrm{n}=108)$. Malay female represented the highest frequency compared to Chinese, Indian and other races in Malaysia (73.1\% vs. 16.7\%, $7.4 \%, 2.8 \%)$. The mean value of IL-6 was higher $(91.50 \mathrm{pg} / \mathrm{ml})$ than IL-10 $(44.79 \mathrm{pg} / \mathrm{ml})$ in positive anti-SSA/Ro compared to control group (20.48 $\mathrm{pg} / \mathrm{ml}$ ). Our data also demonstrated that anti-SSA/Ro was significantly associated with IL-6 ( $<<0.005$ ) IL-10 ( $<<0.001$ ). In contrast, no association between anti-SSB/La with both cytokines. Level of pro-inflammatory cytokine IL- 6 was shown to have higher levels compared to anti-inflammatory cytokine IL-10. These data suggest that IL-6 levels may directly contribute to the formation of autoantibodies in female with anti-SSA/Ro ( $<<0.05$ ) but not anti-SSB/La. Further analysis is necessary to identify the levels of cytokine with the onset of auto-antibody formation. This could provide preliminary data on the evaluation of early detection in autoimmune progression in the future.
\end{abstract}

Keywords: Cytokine; Interleukin-6; Interleukin-10; Anti-SSA/Ro; Anti-SSB/La, Anti-inflammatory, Pro-inflammatory 


\title{
LEPTIN ADMINISTRATION INDUCES THE EXPRESSION OF TUMORIGENIC GENES IN THE STOMACH OF MALE SPRAGUE-DAWLEY RATS
}

\author{
Isyraqiah, Faizatul $^{1}$; Kutty, Methil Kannan²; Durairajanayagam, Damayanthi' ${ }^{1}$; Singh, Harbindar Jeet ${ }^{1}$
}

${ }^{1}$ Faculty of Medicine, Universiti Teknologi MARA, Sungai Buloh, Selangor, Malaysia.l2 Faculty of Medicine, Lincoln University College, Petaling Jaya, Selangor, Malaysia. Email: faizatulisyraqiah@gmail.com

\begin{abstract}
Leptin has been shown to promote the growth of gastric cancer cells in vitro. However, it is unknown if leptin can directly induce the development of gastric cancer in vivo. This study therefore determines if chronic leptin treatment leptin induces gastric carcinogenesis in rats. Sixteen, male Sprague-Dawley rats, aged 6 weeks, were divided into two groups ( $\mathrm{n}=8$ per group). Group 1 served as control. Group 2 was given intrap eritoneal injections of leptin $(60 \mu \mathrm{g} / \mathrm{kg} /$ day $)$ for 40 weeks. Body weight and water intake were measured weekly. Rats were euthanized after 40 weeks of treatment, and stomachs were collected for histopathological examination, microarray, and RT-qPCR analysis. Data were analysed using one-way ANOVA and Fisher's exact test. Compared to control, $12.5 \%$ of leptin-treated rats developed a large red-coloured tumour nodule at the pyloric antrum of the stomach. Microscopically, 25\% of leptin-treated stomachs exhibited hyperplasia and dysplasia. Microarray analysis revealed significant upregulation of genes that included Furin (protein maturation), Eef1a1 and Eif4g2 (translation factors), Tmed2 (vesicular trafficking), Rab7a (plasma membrane trafficking), Rfwd2 (protein degradation), Fth1 and Ftl1 (oxygen transport), Tspan8, Tspan1, Fxyd3, and Rack1 (cell migration), Pde4d (signal transduction), Nupr1 and Ybx1 (transcription factors), Ptma and Tmem134 (oncogenes), Srsf2 (mRNA maturation), and Reep5 (cell proliferation). In conclusion, leptin administration induced gastric hyperplasia and dysplasia, and significantly upregulated the expressions of carcinogenic genes in the stomach of rats. These findings underscore a potential role of leptin in the increased prevalence of gastric cancer amongst obese people.
\end{abstract}

Keywords: Leptin; Gastric cancer; Obesity 


\title{
FUNCTIONAL ROLE OF FRINGE IN TUMOR ANGIOGENESIS
}

WEI KANG, CHENG ${ }^{1}$; KAUR, GURJEET'1; ADRIAN, HARRIS ${ }^{2}$; CHERN EIN, OON ${ }^{1}$

\author{
${ }^{1}$ Institute for Research in Molecular Medicine (INFORMM), Universiti Sains Malaysia, Penang, 11800, Malaysia. ${ }^{2}$ Weatherall Institute of \\ Molecular Medicine, John Radcliffe Hospital/Headley Way, Oxford OX3 9DS, United Kingdom
} Email: teddycheng587@gmail.com

\begin{abstract}
Clear Cell Renal Cell Carcinoma (CCRCC) is the most common type of kidney cancer with abnormally high abundance of blood vessels. Current treatments for CCRCC include bevacizumab, sunitinib \& nivolumab however some patients may acquire resistance to current treatment. Fringe is a regulator of Notch Signalling which is a pathway implicated in angiogenesis, however very little is known about the role of Fringe in tumour angiogenesis. This project aims to study the role of Fringe in tumour angiogenesis. Fringe gene knockdown was performed on Ea hy 926 endothelial cell line using lentiviral transduction. These cells were then subjected to cell MTT assay, scratch assay, tube formation assay and qPCR for gene expression studies. Fringe knockdown in Ea hy926 cells (shFringe) resulted in decreased proliferation and migration compared to Ea hy926 empty vector control (EV). Down-regulation of adhesion related genes ICAM-1, ITGA5 and VE-cadherin were found in Fringe silenced cells, suggesting that Fringe plays a role in cell adhesion which is an important aspect of the angiogenesis process. The result of tube formation assay showed inhibited tube formation in shFringe compared to EV. This project is expected to shed light on the role of Fringe in tumour angiogenesis which may provide a novel strategy for cancer treatment. On-going work includes co-culture assay with renal cancer cell line to determine the effect of Fringe in renal tumour angiogenesis.
\end{abstract}

Keywords: Clear cell; Renal cell carcinoma; Ea hy926; ICAM-1; ITGA5; VE-cadherin 


\title{
INVERTEBRATES LIVING IN POLLUTED ENVIRONMENTS ARE A POTENTIAL SOURCE OF NOVEL ANTITUMOR MOLECULE(S)
}

\author{
MR MOHAMMAD; S JEYAMOGAN; NA KHAN; K. SAGATHEVAN; R SIDDIQUI
}

Department of Biological Sciences, Sunway University, Selangor, Malaysia

Email: ruqaiyyahs@sunway.edu.my

\begin{abstract}
The morbidity and mortality related to cancer has remained significant despite developments in therapeutic interventions and supportive care. Estimates from the International Agency for Research on Cancer (IARC), indicate 14.1 million new cancer cases and 8.2 million cancer related deaths worldwide in 2012. Thus, there is a need for more potent anticancer agents. Animals living in polluted environments are a potential source of anticancer agents. Under polluted milieus, species such as crocodiles and cockroaches, feed on rotten meat, are exposed to heavy metals, tolerate high levels of radiation, are among the very few species to survive the catastrophic Cretaceous-Tertiary extinction event, yet cancer is rarely reported in these species. Thus, it is sensible to speculate these animals have developed mechanisms to defend themselves against cancer. Here, we tested Tiger prawns, cherry red centipede, dubia cockroaches and house crickets for anticancer activity against Henrietta Lacks (HeLa) cells and prostate cancer (PC3) cells. Using cytotoxicity assays, growth inhibition assays and cell survival assays, the results reveal ed that lysates of the tiger prawn body and gut, cherry red centipede head, body and haemolymph, and house cricket upper abdomen and gut exhibited significant cytotoxic effects against both cell lines tested. Studies are in progress to determine the effects of lysates on normal human cells and to identify the active molecules. These findings will stimulate research in finding therapeutic molecules from unusual sources and has potential for the development of novel anticancer compound(s) that may also overcome current drug resistance.
\end{abstract}

Keywords: Anticancer; Animals-based compounds; anticancer molecule(s); natural anticancer agents 


\title{
GUT MICROBES OF INVERTEBRATES LIVING IN POLLUTED ENVIRONMENTS ARE POTENTIAL SOURCE OF NOVEL ANTICANCER AGENTS
}

\section{NAVEED AHMED KHAN; MORHANA SOOPRAMANIEN; SHARENI JEYAMOGAN; NOOR AKBAR; K. SAGATHEVAN; RUQAIYYAH SIDDIQUI}

Department of Biological Sciences, Faculty of Science and Technology, Sunway University, Malaysia

Email: naveed5438@gmail.com

\begin{abstract}
Animals living in polluted environments are routinely exposed to radiation, heavy metals and other carcinogenic materials, yet they have rarely been reported to develop cancer. For example, cockroaches can withstand radiation level 15 times more than what can kill humans. It is logical to propose that such species must have developed anticancer mechanisms and/or produce anticancer molecules. The overall aim of this study was to determine whether gut microbes of animals/pests living in polluted environments; such as cockroaches, are a potential source of novel anticancer agents. A range of invertebrates were collected including, Acheta domesticus (cricket), Anadara granosa (blood clam), Blaptica dubia (cockroach), Penaeus monodon (tiger prawn) and Scolpendra subspinipes (centipede). Invertebrates were dissected and their gut bacteria were identified. The conditioned media were prepared by incubating bacteria in RPMI for $24 \mathrm{~h}$ at $37^{\circ} \mathrm{C}$. Next day, cultures were centrifuged and CM was filtered using $0.4 \mu \mathrm{m}$ pore size filter. The conditioned media were used to conduct cytotoxicity assays, cell survival assays and cell growth assays against a panel of cancer cell line; HeLa (cervix cancer) and PC3 (prostate cancer) and a normal cell line; HaCaT (aneuploid immortal keratinocyte). The results revealed that conditioned media from tiger prawn (Pseudomonas oryzihabitans) and centipede (Kocuria varians) exhibited significant cytotoxic and growth inhibitory effect against the 3 cell lines selected, thereby indicating the potential of those 2 conditioned media as anticancer agents. However, further studies are in progress to identify and characterize the active molecules.
\end{abstract}




\title{
ASSOCIATION OF SALTED FISH CONSUMPTION WITH NASOPHARYNGEAL CANCER RISK IN ASIAN POPULATIONS: A SYSTEMATIC REVIEW AND META-ANALYSIS
}

\author{
SIMON I, OKEKPA ${ }^{1}$; ; RABIATUL BASRIA S.M.N, MYDIN ${ }^{*}$; ERNEST, MANGANTIG²; KAUR, GURJEET ${ }^{4}$; YUSRI, \\ MUSA $^{1}$
}

${ }^{1}$ Oncological and Radiological Sciences Cluster, Advanced Medical and Dental Institute, Universiti Sains Malaysia, 13200 Bertam, Kepala Batas, Pulau Pinang. ${ }^{2}$ Regenerative Medicine Cluster, Advanced Medical and Dental Institute, Universiti Sains Malaysia, 13200 Bertam, Kepala Batas, Pulau Pinang. ${ }^{3}$ Department of Medical Laboratory Science, Faculty of Health Sciences, Ebonyi State University, Abakaliki, 840001 Ebonyi state, Nigeria. ${ }^{4}$ Institute for Research in Molecular Medicine, Universiti Sains Malaysia, Penang, Malaysia Email: siokekpa@student.usm.my

\begin{abstract}
Nasopharyngeal carcinoma (NPC) risk factors have been associated with diets, life style and viral infections. NPC is more rampant in Asian populations than non-Asian countries. Our study aims to evaluate the authenticity of the evidence provided by case control studies on the relationship between salted fish consumption and risk of NPC in Asia. Literature search of PubMed databases, Google Scholar and Science Direct were conducted on salted fish as a risk factors of NPC. Included in the study were articles published between 2009 and 2017 and focused specifically on NPC cases and salted fish consumption as a risk of NPC. Excluded in the study were all articles published earlier than 2009 and studies relating to other cancers. Data were independently extracted from the included articles by two different academics and matched. Metaanalysis were performed on the data obtained, generating forest and funnel plots via R package Meta. Meta-analysis revealed significant association of salted fish to NPC risk with random effect model score showing OR of 1.41 at $95 \%$ confidence interval (CI) of $1.13-1.75$ (P<0.01). This study suggests that salted fish consumption might be associated with NPC risk in Asia. Further studies is required in order to elucidate the molecular mechanisms and to determine if the associated pathway could serve as a therapeutic target. Acknowledgments: The authors would like to thank Universiti Sains Malaysia (short-term research grant: 304/CIPPT/6315073) for sponsoring this work.
\end{abstract}

Keywords: Nasopharyngeal carcinoma risk factors; Dietary and Cancer Risk in Asian; Salted fish consumption and Cancer Risk Factors; Nasopharyngeal carcinoma 


\title{
EXPRESSION OF E-CADHERIN IN ORAL POTENTIAL MALIGNANT DISORDERS AND ORAL CANCERS
}

\section{SRIDEVI, UGRAPPA}

Department of Oral Medicine \& Radiology, Faculty of Dentistry, AIMST Dental Institute, AIMST University, Kedah, Malaysia. Email: srideviugrappa@gmail.com

\begin{abstract}
Oral cancer is subset of head and neck cancer and remains as significant burden worldwide in terms of diagnosis, treatment and prognosis. Cadherin's are superfamily of calcium dependent trans-membrane proteins that act as adhesion molecules and maintain epithelial stability with various roles including development, morphogenesis, organogenesis and carcinogenesis. The purpose of the present study was to assess the expression of E-cadherin (E-Cad) in oral potential malignant disorders and oral carcinomas and comparison with normal mucosa After clinicopathological confirmation, 10 samples from each of oral leukoplakia (OL), oral lichen planus (OLP), oral sub-mucous fibrosis (OSMF), oral squamous cell carcinoma (OSCC) and normal oral mucosa (NOM) as control group were selected for the study. All the samples were assessed for the expression of E-Cad by immunohistochemical study. Upon assessing the expression of E-cad in OL, OSMF, OLP and OSCC, overall majority of the samples with OSCC (90\%), OL (80\%), OLP (70\%) and OSMF (60\%) showed mild to moderate expression of E-cad staining, which was suggestive of reduction in dysplastic cells in comparison to NOM. This difference in expression and variation of E-cad upon comparison with normal mucosa was statistically significant $(\mathrm{P}<0.001)$. There was no correlation of degree of E-cad with the degree of dysplasia or the tumor differentiation of oral cancer, since there is a variation in its expression of its value as a prognostic marker is questionable.
\end{abstract}

Keywords: E-Cadherin; Immunohistochemistry; Oral carcinoma; Oral potential malignant disorders 


\title{
BIOMARKER DISCOVERY ON MICROARRAY DATA USING INTEGRATED ASSOCIATIVE CLASSIFICATION
}

\author{
ONG HUEY FANG ${ }^{*}$, NORWATI MUSTAPHA ${ }^{2}$, AIDA MUSTAPHA ${ }^{2}$, HAZLINA HAMDAN ${ }^{2}$
}

${ }^{1}$ Center for Degree Studies, University Malaysia of Computer Science \& Engineering, Putrajaya 62000, Malaysia. ${ }^{2}$ Faculty of Computer Science and Information Technology, University Putra Malaysia, Selangor 43400, Malaysia

Email: onghueyfang@unimy.edu.my,norwati@upm.edu.my

\begin{abstract}
Microarrays are one of the powerful genomic technologies used in biomarker discovery. In data mining, gene selection is a process used to identify genes or biomarkers that are strongly relevant to cancer subtypes. Whereas classification is a process used to discover hidden biomarkers in microarray profiles for accurate cancer diagnosis or prediction. Although many studies had shown promising results in both ge ne selection and classification on microarray data, they are usually executed in separate analysis and did not take into consideration the quality of biomarkers. Therefore, to address data qualification in biomarker discovery, both processes should be integrated into the same analysis, with the assumption that a good selection will result in a good classifier, or the other way round. The increasing trend of integrated analysis has also shifted biomarker discovery from purely data-centric to incorporating prior biological knowledge to develop interpretable biomarker models. Sufficient interpretability is essential for researchers to understand the underlying biological mechanisms, and in diagnosing and treatment of cancers. However, most of the current works integrated only single biological data such as functional annotations, metabolic pathways, or protein-protein interactions in a single analysis. Moreover, existing works generates a large number of candidates, which require more efforts to further experiment and evaluate the potential biomarker genes. Hence, this study aims to resolve the challenges in biomarker discovery by proposing a systematic integrative biomarker discovery model for microarray data. The main components of the model consisted of a modified associative classification method and multiple biological sources. Associative classifications have proven to produce higher prediction results compared with other traditional classification and rule-based methods. It is also a method that is capable to uncover interesting relationship or associations among genes, which is coherent with the nature of microarray data. The proposed model is capable of identifying a smaller set of biomarker genes with better prediction accuracy and interpretability.
\end{abstract}

Keywords: Biomarker discovery; Associative classification; Microarray; Gene expression; Integrated 


\title{
TIGERNUT (CYPERUS ESCULENTUS) EXTRACTS INDUCE A DIFFERENT TYPE OF CELL CYCLE ARREST IN MDA-MB231 AND MCF7 \\ ACHORIBO, SEYRAM ELOM; ONG, MING THONG
}

Institute for Research in Molecular Medicine, Universiti Sains Malaysia, 11800 Minden, Pulau Pinang, Malaysia Email: achoribo@yahoo.fr

\begin{abstract}
In many developing countries, the delay in cancer detection and treatment is mainly due to the cost involved. This has also led to the frequent use of orthodox medicine or herbal products in disease treatments. Therefore, proper investigation on the mechanism of action of local medicinal plants is crucial to ascertain the proper use of the plants. Tigernut is an underutilized crop in Ghana, with high nutritional values, but consumed raw as a snack or as milk. Cytotoxicity screen of its extracts showed an anti-proliferative effect on MCF7 and MDA-MB-231 breast cancer-origin cell lines. The present work investigated the effect of Tigernut extracts on the cell cycle of the mentioned cells and has attempted to elucidate the mechanisms of action involved. The analyses were carried out at cell cycle and cell signaling pathway levels using flow cytometry and Western blotting methods respectively. The extracts have been shown to induce G0/G1 and S phase cell cycle arrest in MCF7 and MDA-MB-231 respectively. The outcomes have been demonstrated to involve the activity of Cyclin D1 and that of ERK1/2, c-Myc, and c-Jun proteins in estrogen receptor cell signaling pathway.
\end{abstract}

Keywords: Tigernuts; Cell cycle; MCF7; MDA-MB231; Cyclin D1 


\title{
CELLULAR CHARACTERIZATION AND TRANSCRIPTOME ANALYSIS FOR IDENTIFICATION OF BIOMARKERS FOR CISPLATIN-RESISTANT BREAST CANCER STEM CELLS
}

\author{
MAY ZIE'; ${ }^{1}$ WAN YONG'; SWEE KEONG²
}

1Department of Biomedical Sciences, Faculty of Science, University of Nottingham, Malaysia campus, Jalan Broga, 43500 Semenyih, Selangor Darul Ehsan, Malaysia. ${ }^{2}$ Marine Biotechnology, School of Ocean and Environment, Xiamen University Malaysia campus, Jalan Sunsuria, Bandar Sunsuria, 43900 Sepang, Selangor.Email: khyx5kmz@nottingham.edu.my

\begin{abstract}
Cisplatin is an effective drug used for metastatic breast cancer treatment. However, development of resistance suppressed its efficacy on breast cancer. Cancer stem cells (CSCs) was proposed to contribute to the development of cisplatin resistance. Therefore, we aim to elucidate the underlying mechanisms that contributes to cisplatin resistance by investigating the cell characteristics and transcriptome expression of cisplatinresistant breast cancer cells, especially the CSCs. Basal-like breast cancer cell line, MDA-MB-231 was used in this study. CSCs were isolated from parental cells and the therapeutic effect of cisplatin on CSCs was compared to that of the parental cells via cell characterization bioassays. PCR array was then conducted to study the expression of cellular-mRNA for each subpopulation. As compared to treated-parental cells, cisplatin reduced CD44+/CD24- population to a lower extent in treated-CSCs. Besides, treated-CSCs displayed lower event of late apoptosis with higher rate of migration, invasion and spheroid formation capacity as compared to treated-parental cells. These cells showed higher expression of Notch signalling-correlated oncogenes including NOTCH1, JAG1 and KLF4 as compared to treated-parental cells. In summary, our data suggests that CSCs are one of the factors that contribute to the development of cisplatin resistance in breast cancer. With that, understanding the role of dysregulated genes induced by cisplatin in CSCs may offer potential development of targets as biomarker or therapeutic targets for cisplatin resistant breast cancer.
\end{abstract}

Keywords: Breast cancer; Cisplatin resistance; Cancer stem cells; Gene expression; Transcriptome 


\title{
GENOTOXICITY OF DIALYSED C-SERUM PRECIPITATE (DCP) OF HEVEA BRASILIENSIS
}

RAMAN@ RAMARAO, MALINI DEVI'; ONG, MING THONG'; YANG, KOK LEE'; ELUMALAI, SUNDERASAN²

1 Institute for Research in Molecular Medicine (INFORMM), Jalan Inovasi, Universiti Sains Malaysia, 11800, Minden Height, Pulau Pinang, Malaysia. ${ }^{2}$ Rubber Research Institute of Malaysia, Malaysian Rubber Board, P.0. Box 10150,Kuala Lumpur, Malaysia.

Email: melly1@ymail.com

\begin{abstract}
Latex C-serum of Hevea brasiliensis was found to have specific in vitro antiproliferative properties towards cancer-origin cell lines with IC50 values situated at nanogram concentration range (Lam et al., 2012, 2015). It has high potential to be applied in cancer treatment in addition to the simplicity of latex preparation and abundant supply of latex. The present study was aimed to further investigate the mutagenicity of Dialysed CSerum Precipitate (DCP) subfraction via Bacteria Reverse Mutation Assay (Ames test), Mouse Lymphoma Assay (MLA) and micronucleus assay. The results indicated that DCP was not mutagenic at a concentration lower than $1 \mathrm{mg} / \mathrm{ml}$ for the five different auxotroph strains namely Salmonella typhimurium (TA 98, TA 100, TA 1535 and TA 1537) and Escherichia coli WP2uvrA pKM101 in the absence and presence of metabolic activation. However, DCP was able to induce chromosomal mutation at low frequency in mouse lymphoma assay and micronucleus assay. It has therefore been concluded that little genotoxic hazard was associated with DCP according to OECD Guidelines.
\end{abstract}

Keywords: Latex C-Serum; Hevea brasiliensis; Mutation; Genotoxicity; L5178Y/Tk+/- 


\title{
PRECLINICAL TOXICOLOGY AND CLASTOGENICITY STUDY OF A NOVEL SIRTUIN INHIBITOR IN VIVO
}

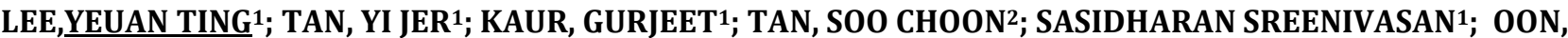 CHERN EIN 1}

${ }^{1}$ Institute for Research in Molecular Medicine, Universiti Sains Malaysia, 11800 Minden, Pulau Pinang, Malaysia.. ${ }^{2}$ Usains Biomics Laboratory Testing Services Sdn. Bhd., 016, Complex Eureka, 17, Jalan Universiti, 11800 Gelugor, Pulau Pinang Email: yeuanting93@gmail.com

\begin{abstract}
Sirtuins (SIRTs) are class III histone deacetylases (HDACs) linked to various diseases such as cancer, diabetes, neurodegenerative and cardiovascular diseases, thus SIRTs are attractive targets for the development of pharmaceuticals. Over-expression of SIRT1 and SIRT2 proteins have been reported in many cancers, mainly by providing tumour cell survival advantage and resistance to therapy by inhibiting apoptosis and allowing unchecked cell division. BZD9L1 is a novel sirtuin inhibitor with demonstrated anti-cancer activities in colorectal cancer. This project aims to to evaluate its acute toxicity and clastogenicity profile in BALB/c mice. In vivo acute toxicity study was performed in female BALB/c mice treated with $2000 \mathrm{mg} / \mathrm{kg}$ of BZD9L1 and screened for signs of toxicity for two weeks after administration via oral gavage. Bone marrow chromosomal aberration assay was conducted in BALB/c mice treated with BZD9L1 at concentrations of 500, 1000 and $2000 \mathrm{mg} / \mathrm{kg}$, after which the bone marrow was examined $24 \mathrm{hr}$ post treatment. Mice exhibited no behavioural distress and no observable toxicity symptoms or death. In addition, no pathological changes in major organs was observed in mice treated with BZD9L1 at $2000 \mathrm{mg} / \mathrm{kg}$. BZD9L1 demonstrated no effect on mitotic index of mice bone marrow cells and no significant induction of chromosomal aberration was found, suggesting BZD9L1 is not clastogenic.
\end{abstract}

Keywords: Sirtuin; BZD9L1; Acute toxicity; Clastogenicity; Chromosomal abberation 


\title{
EXPRESSION OF CIRCULATING MIR-101 AND MIR-744 IN NASOPHARYNGEAL CARCINOMA AND THEIR PERFORMANCE AS DIAGNOSTIC BIOMARKERS
}

\author{
AHMAD, AZMIR'; VIJAYA MOHAN, SIVANESAN²; LU PING, TAN²; TOLOS, SITI MARPONGA3; TUMIAN, \\ AFIDALINA $^{4}$; ABDULLAH, KAHAIRI ${ }^{5}$; KADERI, MOHD ARIFIN ${ }^{6}$
}

\begin{abstract}
1 Department of Biomedical Science, Kulliyyah of Allied Health Sciences, International Islamic University Malaysia (IIUM), Jalan Sultan Haji Ahmad Shah, Bandar Indera Mahkota, 25200 Kuantan, Pahang, Malaysia. ${ }^{2}$ Molecular Pathology Unit, Cancer Research Centre, Institute for Medical Research, Jalan Pahang, 50588 Kuala Lumpur, Malaysia. ${ }^{3}$ Department of Computational and Theoretical Science, Kulliyyah of Science, IIUM, Jalan Sultan Haji Ahmad Shah, Bandar Indera Mahkota, 25200 Kuantan, Pahang, Malaysia. ${ }^{4}$ Department of Computer Science, Kulliyyah of Information and Communication Technology, IIUM, P.0. Box 10, 50728 Kuala Lumpur, Malaysia. 5 Department of hinolaryngology, Kulliyyah of Medicine, IIUM, Jalan Sultan Haji Ahmad Shah, Bandar Indera Mahkota, 25200 Kuantan, Pahang, Malaysia. ${ }^{6}$ Department of Biomedical Science, Kulliyyah of Allied Health Sciences, IIUM, Jalan Sultan Haji Ahmad Shah, Bandar Indera Mahkota, 25200 Kuantan, Pahang, Malaysia. Email: azmir004@gmail.com
\end{abstract}

\begin{abstract}
Our previous study showed that miR-101 and miR-744 were deregulated in nasopharyngeal carcinoma (NPC) tissues as compared to control tissues with certain diagnostic performance. Thus, we would like to observe the expression of both miRNAs in plasma of NPC patients as compared to control subjects and analyse their diagnostic performance. Plasma were collected from 33 NPC patients and 33 control subjects and subjected to total RNA extraction. Reverse transcription, pre-amplification and quantitative polymerase chain reaction (qPCR) were performed on the total RNA extract using Taqman microRNA Assays. Fold-change of the miRNAs were calculated using 2- $\Delta \Delta$ Cq formula and statistical analyses were performed using SPSS version 20 software. The qPCR results showed that miR-101 and miR-744 ( $>0.05$ ) were up-regulated in NPC as compared to control plasma. Receiver operating characteristic curve analysis showed that area under curve (AUC) for miR-101, miR-744 and combination of miR-101 and miR744 were $0.374,0.410$ and 0.437 , respectively, in discriminating NPC patients from control subjects, but they have AUC of 0.647 , 0.69 and 0.599 , respectively, in discriminating early from late stage NPC. The up-regulation of miR-101 and miR-744 have been reported in previous studies indicating the consistency of our findings. Although we found that they have poor diagnostic values in plasma for discriminating NPC patients from control subjects, they have better diagnostic values in discriminating early from late stage NPC. Therefore, we have successfully reported the upregulation of miR-101 and miR-744 in plasma of NPC with respective diagnostic performance.
\end{abstract}

Keywords: Nasopharyngeal carcinoma; Gene expression; miR-101; miR-744; Diagnostic biomarkers 
IMMUNOHISTOCHEMICAL EXPRESSION OF IGFBP-2 PROTEIN IN NORMAL CERVIX, CERVICAL INTRAEPITHELIAL NEOPLASIA AND SQUAMOUS CELL CARCINOMA OF THE CERVIX

\title{
LEE, YUNG JEN; KAUR, GURJEET
}

Institute for Research in Molecular Medicine, Universiti Sains Malaysia, 11800 Minden, Pulau Pinang, Malaysia

Email: lyungjen_88@hotmail.com

\begin{abstract}
Cancer of the cervix is the third most common cancer amongst females in Malaysia, and the fourth-most common cause of death from cancer globally. The availability of diagnostic biomarkers for cervical cancer is of utmost importance to help improve screening and diagnostic methods. IGFBP-2 belongs to a family of highly-conserved proteins that have been shown to exhibit tumorigenic effects, as they are overexpressed in many malignancies. This study aimed to analyze the immunohistochemical expression pattern of IGFBP-2 protein in normal cervix, cervical intraepithelial neoplasia (CIN) and squamous cell carcinoma (SCC) of the cervix, using commercial tissue microarrays. Ten cases of normal cervix, 21 cases of CIN and 42 cases of SCC were immunohistochemically stained for IGFBP-2 using a rabbit monoclonal antibody to IGFBP-2 (Abcam), and endometrial carcinoma tissue was used as positive control. Immunohistochemistry showed positive expression of IGFBP-2 in all cases, with cytoplasmic staining of squamous epithelial cells and stromal inflammatory cells. The histoscore was calculated using a semi-quantitative scoring method. The results demonstrated a significant difference in IGFBP-2 expression between normal cervix, CIN and SCC ( $p=0.001$ ), with expression in CIN being significantly higher than normal cervix $(\mathrm{p}=0.010)$ and expression in SCC even more significantly higher than normal cervix $(\mathrm{p}<0.001)$. The histoscore of IGFBP-2 was not significantly associated with age ( $p=0.732$ ), CIN Bethesda grading ( $p=0.476)$ or pathological staging of SCC $(\mathrm{p}=0.108)$. In conclusion, IGFBP-2 appears to play a role in cervical carcinogenesis, and could be a potential biomarker for the diagnosis of cervical cancer and cervical intraepithelial neoplasia.
\end{abstract}

Keywords: Cervical cancer; Cervical intraepithelial neoplasia; Squamous cell carcinoma; IGFBP-2; Immunohistochemistry 


\title{
EVALUATION OF MOLECULAR CHANGES OF GENES INVOLVED IN CELL CYCLE AND APOPTOSIS IN RELATION TO CERVICAL CARCINOGENESIS
}

\author{
BALASUBRAMANIAM, SHANDRA DEVI; KAUR, GURJEET; BALAKRISHNAN, VENUGOPAL; OON, CHERN EIN
}

Institute for Research in Molecular Medicine, Universiti Sains Malaysia, 11800 Minden, Pulau Pinang, Malaysia Email: shandrabala@gmail.com

\begin{abstract}
Cell cycle regulators influence both cell division and programmed cell death or apoptosis. Healthy cells have a perfect balance between cell proliferation and cell death. An imbalance can lead to diseases including cancer. In high-risk human papillomavirus (HPV) related cervical cancer, the viral oncoproteins E6 and E7 integrate into the host cell genome leading to genomic instability and progression to cancer. The study aimed to profile the expression of cell cycle and apoptosis mediated genes in HPV-related precancerous cervical intraepithelial neoplasia (CIN) lesions, and cancer lesions, using formalin fixed paraffin embedded (FFPE) tissues. Total RNA was extracted from 12 FFPE samples, consisting of 3 normal cervix as control, 3 low-grade CIN (CIN 1), 3 high-grade CIN (CIN 2/3) and 3 squamous cell carcinoma (SCC). The extracted RNA was hybridized to human transcriptome array (HTA) 2.0 Affymetrix. Gene expression analysis was evaluated using Affymetrix transcriptome analysis console software. The result were then validated using nanostring PanCancer pathway array and analyzed using nanostring software 3.0. The results showed a differential expression of cell cycle and apoptosis mediated genes such as CDKN2A, PKMYT1, MCM2 and TTK whereby these genes showed significant fold-change $(>2$; p-value $<0.05)$. There was no significant difference in genes between normal cervix and low-grade CIN. The results concur with the hypothesis that HPV oncoproteins indirectly activate genes involved in cell cycle proliferation and p53-dependent or independent apoptosis. Deregulation of these genes causes cell to progress into a cancerous cell.
\end{abstract}

Keywords: Cervical cancer; High-risk HPV; Cell cycle; Apoptosis; Gene expression 


\title{
CORRELATION OF LEPTIN WITH CLINICO-PATHOLOGICAL FEATURES OF BREAST CANCER
}

\author{
AL-SHIBLI, SAAD M.1; AMJAD, NASSER M.2; AL-KUBAISI, MUNA KH. ${ }^{3}$; HARUN, NORRA4
}

${ }^{1}$ Department of Basic Medical Sciences, Faculty of Medicine, International Islamic University Malaysia, Pahang, Malaysia. ${ }^{2}$ Department of Surgery, Faculty of Medicine, International Islamic University Malaysia, Pahang, Malaysia, ${ }^{3}$ Department of Gynecology\& Obstetric, Faculty of Medicine, International Islamic University Malaysia, Pahang, Malaysia, ${ }^{4}$ Department of Histopathology, Hospital Tengku Ampuan Afzan, Kuantan, Malaysia,Email: salshibli2004@yahoo.com

\begin{abstract}
Leptin is a multifunctional hormone produced mainly by adipocyte. Leptin and its receptor have long been found associated with breast cancer. Our aim is to investigate the correlation between Leptin/Leptin receptor and the clinico-pathological features of breast cancer. Blood samples for ELISA, tissue samples from tumours and adjacent breast tissue were taken from 51 women with breast cancer with a control group of 40 women with negative mammogram. Leptin and Leptin receptor in the tissues were estimated by immunohistochemistry (IHC). They were localized at subcellular level by immunocytochemistry using transmission electron microscopy TEM. Our results showed significant difference in serum leptin level between control and the patient group, but no difference between pre and post-operative levels in the patient group. By IHC, we found that majority of the breast cancer cells studied, stained positively for leptin and leptin receptors. Majority of the patients with distant metastasis were associated with high leptin and leptin receptor expression. TEM views both Leptin and Leptin receptor were found highly concentrated within and around the nucleus of the cancer cells, indicating nucleus is their principal seat of actions. However, presence of high concentration of leptin does not necessarily prove its over-expression, because it could be internalized from outside by leptin receptor in the cells. In contrast, leptin receptor is definitely over-expressed in the ductal breast cancer cells. We conclude that reducing leptin levels, blocking its downstream tissue specific signal transduction, and/or blocking the upstream leptin receptor pathway might help in prevention and therapy of breast cancer.
\end{abstract}

Keywords: Breast Cancer; Leptin; Leptin Receptors; Expression 


\title{
METHADONE HYDROCHLORIDE INDUCED APOPTOSIS ON LEUKAEMIA CELL LINES KUA, VEE MAY DIANNE; LAI, NGIT SHIN; TAN, SOO CHOON
}

Institute for Research in Molecular Medicine, Universiti Sains Malaysia, 11800 Minden, Pulau Pinang, Malaysia. Email: kvmdianne@gmail.com

\begin{abstract}
Leukaemia is the most common cancer diagnosed in children. Methadone hydrochloride is a synthetic drug that is commonly used in the maintenance treatment for drug addiction. The objective of this research is to determine the cytotoxic activity and apoptotic effects of methadone hydrochloride treatment towards two leukaemia cell lines which are CCRF-CEM and HL-60. In MTS assay, the cytotoxicity results showed that IC50 values for both cell lines exceeded the standard required for cytotoxic activity of pure compound ( $\leq 10 \mu \mathrm{g} / \mathrm{mL})$ for the compound to be considered active as a potent chemotherapeutic agent. Methadone hydrochloride did not induce apoptosis that involved DNA fragmentation in CCRF-CEM cells as no characteristics DNA ladder pattern was observed. On the other hand, characteristics DNA ladder pattern was observed in methadone hydrochloride-treated HL-60 cells. Formation of comets was seen in methadone hydrochloride-treated CCRF-CEM and HL-60 cells with varying degree of DNA damage. Methadone hydrochloride induced apoptosis in CCRF-CEM cells through Type I extrinsic pathway of apoptosis, involved the up-regulation of caspase 8 expression and down-regulation of p53 and survivin expression. As for HL-60 cells, methadone hydrochloride induced apoptosis through Type II extrinsic pathway of apoptosis whereby it involved the up-regulation of Bid and caspase 8 expressions and downregulation of Bcl-2, p21, and survivin expression. In conclusion, the present study has shed some insight on the effects of methadone hydrochloride treatment on CCRF-CEM and HL-60 cells in term of cell cytotoxicity, the degree of DNA fragmentation, and the expression level of apoptosis-related proteins.
\end{abstract}

Keywords: Apoptosis; Leukaemia; Methadone hydrochloride; Type I extrinsic pathway; Type II extrinsic pathway 


\title{
A NOVEL SIRTUIN INHIBITOR (BZD9L1) AS AN ADJUNCT TO CHEMOTHERAPY IN COLORECTAL CANCER
}

\author{
YI JER TAN'; YEUAN TING LEE'; SVEN H PETERSEN²; GURJEET KAUR'; KOJI KONO2,4,5; SOO CHOO TAN³; CHERN \\ EIN OON ${ }^{1}$
}

\begin{abstract}
${ }^{1}$ Institute for Research in Molecular Medicine (INFORMM), Universiti Sains Malaysia, Penang, 11800, Malaysia. ${ }^{2}$ Cancer Science Institute of Singapore, National University of Singapore, Singapore, Singapore. ${ }^{3}$ USains Biomics Laboratory Testing Services Sdn. Bhd., Universiti Sains Malaysia, Suite 016 Ground Floor, Eureka Complex, Penang, 11800, Malaysia. ${ }^{4}$ Department of Surgery, National University of
\end{abstract} Singapore, Singapore, Singapore. ${ }^{5}$ School of Medicine, Fukushima Medical University, Fukushima, Japan.Email: richard_tan54@hotmail.com

\begin{abstract}
Colorectal cancer is one of the most common cancer with high mortality rate worldwide. Despite medical advances, metastatic cancer patients undergoing systemic chemotherapy often suffer from acquired resistance and side effects. Recently, targeted therapy is gaining popularity in combination with standard chemotherapy drugs in treating cancer due to its effectiveness, specificity and lesser side effects in whole. Sirtuins are Class III histone deacetylases (HDACs) which play important roles in epigenetic regulation in cancer. This work aims to study the effect of a novel SIRT1 and SIRT2 inhibitor BZD9L1 in combination with a standard chemotherapy drug 5-fluorouracil (5-FU) on colorectal cancer cell line HCT116 in vitro and in vivo. HCT116 cells were treated with BZD9L1 and/or 5-FU to assess the combination effect on cell viability, cell survival, cell death and senescence using CyQuant assay, clonogenic assay, flow cytometry (Annexin V/PI) and Senescence-associated $\beta$-Galactosidase assay respectively. Molecular players involved in BZD9L1 and/or 5-FU mediated cell death were elucidated via qPCR and western blot. The in vivo effects of BZD9L1 in combination with 5-FU were investigated using HCT116 tumour xenograft model in nude mice. Combination treatment with BZD9L1 and 5-FU resulted in synergistic reduction of HCT116 cell viability and survival through cell cycle arrest and apoptosis compared to single treatments. In vivo studies showed combination of both BZD9L1 and 5-FU significantly inhibited tumour growth compared to standalone treatments. In conclusion, combination of 5-FU with BZD9L1 may overcome the limitations of 5-FU-based chemotherapy and provide more effective avenues for cancer treatment.
\end{abstract}

Keywords: BZD9L1; Colorectal cancer; Sirtuin; Targeted therapy; Combination treatment 


\title{
THE EFFECTS OF TETRODOTOXIN ON GROWTH AND EXPRESSION OF NNAV1.5 IN BREAST CANCER CELLS
}

\author{
SHARUDIN, NUR AISHAH; MOHD JAAFAR, MUHAMMAD FIRDAUS; MOKHTAR, NOOR FATMAWATI
}

Institute for Research in Molecular Medicine, Universiti Sains Malaysia, 16150 Kubang Kerian, Kelantan, Malaysia

Email: aishahsharudin23@gmail.com

\begin{abstract}
Tetrodotoxin (TTX) is a potent neurotoxin derives from Tetraodontiformes, an order that includes pufferfish. The major mechanism of action of TTX is inhibition of voltage-gated sodium channels (VGSCs) in excitable tissues e.g. cardiac and nerves that lead to effective immobilization of related organs, even death due to respiratory or heart failure. Recently, TTX is being used in breast cancer palliative care to alleviate severe pain with acceptable cardiac and muscle toxicities whilst disregarding its effect on breast cancer cells. Coincidently, increased VGSCs expression particularly the cardiac isoform Nav1.5 in its splice variant, nNav1.5 in aggressive phenotype of breast cancer raised the opportunity of targeting nNav1.5 to control metastasis. This study aimed to study these effects; TTX on the cell growth of human breast cancer cell lines, MDA-MB-231 and MCF-7 and low dose TTX (10 $\mu \mathrm{M}, 80 \%$ inhibition of the channel's activity) on nNav1.5 expression in MDA-MB-231 cells. MTT assay was used to determine IC50 of TTX and real-time PCR for the measurement of nNav1.5 expression. IC50 of TTX were obtained at $236.6 \pm 1.13 \mu \mathrm{M}$ and $298.1 \pm$ $1.15 \mu \mathrm{M}$ in MDA-MB-231 and MCF-7 cells, respectively. nNav1.5 mRNA expression in MDA-MB-231 cells was significantly downregulated by low dose TTX $(10 \mu \mathrm{M})$. TTX is not a potent anti-proliferative agent but able to inhibit the expression of nNav1.5, in aggressive MDA-MB-231 even at a very low dose concentration. The findings proposed consideration for future clinical study on recurrence and mortality rate among breast cancer patients taking TTX.
\end{abstract}

Keywords: Tetrodotoxin; Voltage-gated sodium channel; Neonatal Nav1.5; Breast cancer 


\title{
CHROMOGENIC IN SITU HYBRIDISATION ANALYSIS REVEALED ELEVATED TRNAIMET EXPRESSION IN TUMOUR VERSUS NORMAL TISSUES
}

\author{
NAM, NOOR AKMAR ${ }^{1}$; OIEN, KARIN²; WHITE, ROBERT J3; LEUNG, HING ${ }^{4}$
}

\begin{abstract}
${ }^{1}$ Dept. of Basic Sciences and Oral Biology, Faculty of Dentistry, Islamic Science University of Malaysia (USIM). ${ }^{2}$ Institute of Cancer Sciences, Wolfson Wohl Cancer Research Centre, University of Glasgow, UK. ${ }^{3}$ Dept. of Biology, University of York, UK. ${ }^{4}$ Cancer Research UK, Beatson Institute, Glasgow, UK. Email: noorakmar@usim.edu.my
\end{abstract}

\begin{abstract}
Introduction: RNA Polymerase III (Pol III) contributes to $10 \%$ of nuclear transcription and is essential for synthesis of short untranslated transcripts, including tRNA and 5S rRNA. Pol III deregulation has been implicated in driving cellular proliferation and transformation, with increased expression of several Pol III specific transcription factors and transcripts. tRNAiMet, a downstream target of Pol III-Brf1-driven transcription is crucial in the initiation of translation and tumour progression. Objectives: To develop a specific probe targeting tRNAiMet and further determine the expression profile in various human tissues. Methods: Chromogenic in situ hybridisation (CISH) technique using specific inhouse tRNAiMet probe was applied on panels of tissue microarrays (TMAs) consisting of various normal and tumour tissues. Expression level were semi-quantitatively scored and classified into weak, moderate and strong. Parallel immunostaining was perform with Brf1 and Ki67 as comparison Results and Discussion: Comparing tumour versus normal tissues of selected sites, 23 out of 32 types of malignant tumours were found to have elevated tRNAiMet expression, these are mainly skin tumours and those arising from epithelial glands including prostate, endometrium and breast. Normal tissues with high proliferation rate such as hair follicle and endometrial lining of the uterine cavity also showed high tRNAiMet expression. Several tissues exhibits elevated tRNAiMet level together with high expression of Brf1 and Ki-67 protein expression. Conclusion: tRNAiMet overexpression is a common characteristics of many tumours, and may serve as useful mechanistic indicator for tumour progression. Further study is essential to delineate downstream effect of tRNAiMet overexpression in cancer.
\end{abstract}

Keywords: RNA Polymerase III; tRNAiMet, Brf1; Chromogenic in situ-hybridisation; Cancer 


\title{
ANTIVIRAL ACTIVITY AGAINST DENGUE VIRUS BY FUSARIUM PROLIFERATUM OPT5 SANDANAMSAMY, SYLVIA ${ }^{1}$; NORAZHARUDDIN, HANNAH ${ }^{2}$; AHMAD, ROSMA ${ }^{1}$; NGIT-SHIN LAI ${ }^{2}$; OSMAN, HASNAH $^{3}$
}

${ }^{1}$ School of Industrial Technology, Universiti Sains Malaysia, 11800 Penang, Malaysia. ${ }^{2}$ Institute for Research in Molecular Medicine (INFORMM), Universiti Sains Malaysia, 11800 Penang, Malaysia. ${ }^{3}$ School of Chemical Sciences, Universiti Sains Malaysia, 11800 Penang, Malaysia. Email: rosmah@usm.my

\begin{abstract}
Flaviviridae, one of the viral families that gives the most diseases to the global population, contributes to dengue virus (DENV) which causes 50 - 100 million cases of dengue hemorrhagic fever or dengue shock syndrome with more than 20000 deaths annually. Up to date, there is no antiviral drug for DENV, therefore, fractions from Malaysian fungal cultures were tested. Fungal cultures were cultivated on fermentation media, and mycelia-free supernatants were extracted (1:1) against methanol and ethyl acetate. Crude fractions from 89 cultures were tested for DENV N2B/3 protease activity inhibition. Most potent crude fraction was further fractioned, and the subfractions were tested using DENV N2B-NS3 protease activity inhibition, confirmed with dengue plaque assay and cytotoxicity as well as GCMS analysis. Fungal culture was identified using 18S rDNA sequencing. DENV N2B-NS3 protease assay revealed that an ethyl acetate fraction from Fusarium proliferatum 0PT5 showed highest inhibition activity against DENV. Active subfraction (R2) at $200 \mu \mathrm{g} / \mathrm{mL}$ showed $95.8 \%$ inhibition against DENV protease activity and its cytotoxicity activity on Vero cells exhibited an $\mathrm{EC}_{50}$ of $2000 \mu \mathrm{g} / \mathrm{mL}$. GCMS analysis revealed that major compounds in the active R2 were hexadecenoic and octadecenoic acids, and pyrrolo [1,2-a] pyrazine-1,4, dione, hexahydro-3-(2 methylpropyl). Virus plaque assay on DENV infected Vero cells with the R2 treatment showed that a dose of $200 \mu \mathrm{g} / \mathrm{mL}$ was nontoxic to Vero cells but inhibited $84.30 \%$ of the DENV. This study could be a benchmark for determining possible antiviral activity from a Malaysian fungal cultures for DENV.
\end{abstract}

Keywords: Dengue virus; Antiviral; DENV NS2B/3 protease; Fusarium proliferatum 


\title{
PREPARATION AND CHARACTERIZATION OF 1,4,7-TRIAZACYCLONONANE,1-GLUTARIC ACID-4,7-ACETIC ACID (NODAGA)-PAMIDRONIC ACID (NOD-PAM) PRECURSOR FOR GALLIUM-68 PET BONE SCAN
}

\author{
ASHHAR, ZARIF ${ }^{1,4}$; YUSOF, NOR AZAH ${ }^{1}$; HASSAN, HISHAR ${ }^{2}$; AHMAD HASSALI, HAZLINA ${ }^{3}$; FIKRI, FATHINUL ${ }^{2}$; \\ MOHD NOR, SITI MARIAM ${ }^{1}$; WAN KAMAL, WAN HAMIRUL BAHRIN ${ }^{3}$; FADZIL, FAKHRURAZI ${ }^{4}$
}

${ }^{1}$ Chemistry Department, Faculty of Science, University Putra Malaysia, Serdang. ${ }^{2}$ Centre for Diagnostics Nuclear Imaging, University Putra Malaysia, Serdang. ${ }^{3}$ Malaysian Nuclear Agency, MESTECC, Bangi. ${ }^{4}$ National Cancer Institute, Kementerian Kesihatan Malaysia, Putrajaya Email: zarifnaim@gmail.com

\begin{abstract}
Bisphosphonates are known to be used in treatment of bone metastases. Recently, researchers had looked into the role of bisphosphonates in bone scan by utilizing gallium-68 as a radiotracer. Notable radiopharmaceuticals such as [68Ga]DOTA-Pamidronic acid were studied and proved to demonstrate good bone-to-background ratio. However, by substituting the DOTA chelator to a more stable chelator such as NODAGA, an improved bone-to-background ratio can be achieved. Thus, this study focuses on the preparation and characterization of NOD-Pam precursor for gallium-68 PET bone. NODAGA was conjugated to Pamidronic acid via NHS ester strategy. The analytical RP-HPLC method was developed and scaled up to preparative RP-HPLC method for purification. The fractions from Semi-Prep HPLC were collected and characterized. The resolution between peak of interest for RP-HPLC method developed was 1.91. The fraction of interest was collected and the $\mathrm{m} / \mathrm{z}$ finding for NOD-Pam fraction was consistent with theoretical m/z (calculated m/z: 591.42; obtained m/z: 591.37 [1M-H]) and had no residue of unconjugated NODAGA chelator. In this present work, NOD-Pam was successfully conjugated and purified accordingly using RP-HPLC method. Previous studies anticipated that strong chelator to gallium-68 stability would confer better target-to-background ratio. Therefore, in order to demonstrate this, further study on [68Ga]NOD-Pam radiolabeling, stability, and animal biodistribution should be performed to permit its utilization for clinical evaluation.
\end{abstract}

Keywords: PET bone scan; Gallium-68; Bisphosphonates; NODAGA; Pamidronic acid 


\title{
RUNX1 AND CRLF2 GENES AMPLIFICATION IN A HIGH HYPERDIPLOID CHILDHOOD ACUTE LYMPHOBLASTIC LEUKAEMIA PATIENT
}

\author{
MOHD DALI, NOR SOLEHA ${ }^{1}$; ZAMRI, DURAR AQILAH ${ }^{1}$; ABDULLAH AZIZ, NURSAEDAH'; ZULKIFLE, MUHAMAD \\ FARID ${ }^{1 ;}$ MOHD PAUZY, LAILATUL HADZIYAH ${ }^{1}$; MOHAMED KAMARUZZAMAN, SITI FATIMAH ${ }^{2}$; KAMALUDIN, \\ NOR RIZAN ${ }^{1}$; CHE MOHD RAZALI, CHE HADIBIAH ${ }^{3}$; ESA, EZALIA ${ }^{1}$; ESWARAN, JEYANTHY ${ }^{4,5}$; MAT YUSOFF, \\ YUSLINA $^{1}$; ZAKARIA, ZUBAIDAH ${ }^{1}$
}

${ }^{1}$ Hematology Unit, Cancer Research Centre, Institute for Medical Research, Jalan Pahang, 50588 Kuala Lumpur, Malaysia; ${ }^{2}$ Department of Pathology, Hematology Unit, Sultan Ismail Hospital, Jalan Persiaran Mutiara Emas Utama, Taman Mount Austin, 81100 Johor Bahru, Johor, Malaysia; ${ }^{3}$ Department of Pediatric, Sultan Ismail Hospital, Jalan Persiaran Mutiara Emas Utama, Taman Mount Austin, 81100 Johor Bahru, Johor, Malaysia; ${ }^{4}$ ewcastle University UK/Malaysia, Northern Institute for Cancer Research, Newcastle University, Newcastle Upon Tyne; ${ }^{5}$ Newcastle University Medicine Malaysia (NUMed Malaysia), EduCity@Iskandar, Iskandar Puteri, Johor, Malaysia. Email: norsoleha@imr.gov.my

\begin{abstract}
In B-cell acute lymphoblastic leukemia (B-ALL), there is a strong correlation between primary chromosomal aberration and the spectrum of secondary mutations observed in that subtype. High hyperdiploid is one of the most common primary subtypes occurs among childhood ALL. RUNX1 gene amplification is related to intrachromosomal amplification of chromosome 21 (iAMP21) where the existence of five or more copies of this gene signal detected by fluorescence in situ hybridization (FISH) is defined as iAMP21. CRLF2 amplification is usually the secondary aberration of iAMP21 that can lead to a poor prognosis. Here we report a case of a paediatric patient with high hyperdiploid B-ALL together with chromosome 21 and CRLF2 amplifications. An eight years old Malay boy was presented with pancytopenia. Bone marrows aspirate showed 90\% blasts, and immunophenotyping confirmed a diagnosis of pre-B-ALL. Conventional karyotyping result was inconclusive. FISH analysis showed high hyperdiploid. We performed high-resolution single nucleotide polymorphism (SNP) array on genomic DNA extracted from bone marrow, and chromosome 21 was revealed to be tetrasomy. Subsequent interphase FISH further delineated this genomic aberration (more than five copies of RUNX1 gene). Multiplex ligation-dependent probe amplification (MLPA) confirmed the amplification of chromosome 21. Besides that, the SNP array also revealed four copies of CRLF2 gene on chromosome Xp22.33. This aberration was confirmed by FISH and MLPA. The patient was treated with chemotherapy and achieved remission at day 8 post-treatment, which demonstrated that patient responded well to treatment. This study may suggest that the high hyperdiploid was the primary abnormality in this patient which was not attenuated by the presence of other aberrations.
\end{abstract}

Keywords: ALL; high hyperdiploid; RUNX1 amplification; CRLF2 amplification; SNP array 


\title{
IDENTIFICATION OF COPY NUMBER ALTERATIONS (CNAS) IN PAEDIATRIC B-CELL ACUTE LYMPHOBLASTIC LEUKEMIA (B-ALL) USING MULTIPLEX LIGATION-DEPENDENT PROBE AMPLIFICATION (MLPA):A PRELIMINARY STUDY
}

\author{
ABDULLAH AZIZ, NURSAEDAH ${ }^{1}$; MOHD DALI, NOR SOLEHA ${ }^{1}$; ZULKIFLE, MUHAMAD FARID ${ }^{1}$; ZAMRI, DURAR \\ AQILAH ${ }^{1}$; MOHD PAUZY, LAILATUL HADZIYAH ${ }^{1}$; KAMALUDIN, NOR RIZAN'; ESA, EZALIA ${ }^{1}$; ESWARAN, \\ JEYANTHY',3; MAT YUSOFF, YUSLINA ${ }^{1}$; ZAKARIA, ZUBAIDAH ${ }^{1}$
}

${ }^{1}$ Hematology Unit, Cancer Research Centre, Institute for Medical Research, Jalan Pahang, 50588 Kuala Lumpur, Malaysia;

${ }^{2}$ Newcastle University UK, Northern Institute for Cancer Research, Newcastle University, Newcastle Upon Tyne; ${ }^{3}$ Newcastle University Medicine Malaysia (NUMed Malaysia), EduCity@Iskandar, Iskandar Puteri, Johor, Malaysia.Email: nursaedah@imr.gov.my

\begin{abstract}
Several genomic discoveries have revealed that the genes related to B-lymphocyte development and differentiation, cell cycle control and haematopoiesis are commonly altered in B-cell Acute Lymphoblastic Leukemia (B-ALL). The identification of copy number alterations (CNAs) is essential in refining individual patient prognosis and guiding disease management. In this study, we prospectively evaluate CNAs in 62 children with newly diagnosed B-ALL using multiplex ligation-dependent probe amplification (MLPA). Patients DNA were screened for the alteration of specific genes within chromosome 21, including RUNX1 and ERG, using MLPA P327 kit. These genes are associated with intrachromosomal amplification of chromosome 21 (iAMP21), a clinically defined B-ALL subtype with poor prognosis. In addition, MLPA P335 kit was applied for the detection of CNAs in B-ALL-related genes, CDKN2A/2B, IKZF1, PAX5, RB1, JAK2, ETV6, BTG1, EBF1 and pseudoautosomal region (PAR) genes (SHOX, CRLF2, CSF2RA, IL3RA and P2RY8). Both of P335 and P327 kits were able to detect CNAs in 52 patients (83.9\%). MLPA analysis revealed that $38.7 \%$ of B-ALL children harbor genes amplification within chromosome 21. Most of B-ALL patients were found to have CNAs in PAR genes; SHOX, CSF2RA, IL3RA, P2RY8 (37.1\%) and CRLF2 (35.5\%). These patients were also observed to have CNAs in CDKN2B (32.3\%), CDKN2A (30.6\%), ETV6 (30.6\%) and PAX5 (27.4\%). Low frequency of CNAs were seen in EBF1 (17.7\%), IKZF1 (16.1\%), BTG1 (12.9\%), JAK2 (9.7\%), ERG (4.8\%) and RB1 (3.2\%). Fluorescence in situ Hybridization (FISH) was performed for validation of RUNX1 and CRLF2 aberrations, and the results obtained were in concordance with the MLPA data. Integration of the CNAs findings by MLPA with the clinical data would provide insights into risk stratification and prognosis for precision medicine in B-ALL children.
\end{abstract}

Keywords: MLPA; B-ALL; FISH; CNAs 


\title{
BZD9L1: ELUCIDATION OF ITS ANTI-ANGIOGENIC POTENTIAL IN COLORECTAL CANCER V.SUBRAMANIAM, AYAPPA ${ }^{1}$; WANG, XIAO MENG ${ }^{2}$; OON, CHERN EIN ${ }^{1}$
}

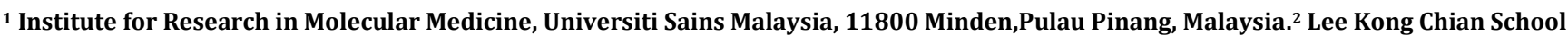
of Medicine, Nanyang Technological University, Singapore, Singapore.Email: ayappa725@gmail.com

\begin{abstract}
Colorectal cancer (CRC) is the third most common cancer globally. CRC depends largely on angiogenesis for growth and metastasis. Much effort has been made to selectively target the angiogenic pathways to restrain tumor growth. However, some CRC patients become resilient to these antiangiogenic drugs and standard therapies. The class III histone deactylase family of sirtuins (SIRTs) have been closely linked to cancer progression but less is known on its activity in regulating tumour angiogenesis. BZD9L1 is a novel sirtuin inhibitor with demonstrated anti-cancer activities. This study aims to investigate the anti-angiogenic potential of BZD9L1 on endothelial cells in vitro. Ea.hy926 endothelial cells (EC) were treated with BZD9L1 at different concentrations and the IC50 of the compound was determined using CyQuant assay. Scratch-wound assay was then carried out to determine the migration ability of the cells after treatment with the compound. Tube formation assay was performed to study the effect of BZD9L1on EC network. The compound showed significant inhibition of EC viability and hampered EC migration and tube formation. Ongoing work includes elucidation of molecular mechanism mediating the anti-angiogenic activity of BZD9L1 and investigation of its effect on colorectal xenograft tumours. The outcome of this project includes the establishment of a potential new drug candidate with anti-cancer and antiangiogenic properties.
\end{abstract}

Keywords: BZD9L1; Colorectal Cancer; Angiogenesis; Sirtuin 


\title{
ASSESSMENT OF TRPV4 ION CHANNEL AND ITS ROLE IN COLORECTAL CANCER CELLS
}

\section{BAHARI, NURUL NADIAH'; JAMALUDIN, SITI YUSRINA NADIHAH'; JAHIDIN, AISYAH HASYILA; ZAHARY, MOHD NIZAM $^{3}$; ABU BAKAR, MOHD HILMI ${ }^{3}$; BAKAR, NOR HIDAYAH ABU'; ALI, ABDUL MANAF4}

1 Faculty of Medicine, Universiti Sultan Zainal Abidin, Medical Campus, Jalan Sultan Mahmud, 20400,Kuala Terengganu, Terengganu, Malaysia. ${ }^{2}$ Faculty of Pharmacy, Universiti Teknologi MARA, Puncak Alam Campus, 42300, Selangor, Malaysia. ${ }^{3}$ Faculty of Health Sciences, ${ }^{4}$ Faculty of Bioresources and Food Industry, Universiti Sultan Zainal Abidin, Besut Campus, 22200,Besut, Terengganu, Malaysia. ${ }^{4}$ Faculty of Bioresources and Food Industry, Universiti Sultan Zainal Abidin, Gong Badak Campus, 21300, Kuala Terengganu, Terengganu, Malaysia. Email: nnbahari@gmail.com

\begin{abstract}
The transient receptor potential (TRP) channels are non-selective cation channels that consist of seven subgroups displaying different ion selectivity, physiological functions and activation mechanisms. TRP vanilloid 4 (TRPV4) is a member of TRPV family which shows permeability to both $\mathrm{Ca} 2+$ and $\mathrm{Na}+$. It is activated by diverse stimuli including both physical and chemical. TRPV4 is found in various types of tissues such as kidneys, airway smooth muscle and lungs, where it participates in many cellular processes including mechanosensation, cell volume regulation and osmoregulation. This study aimed at investigating the potential role of TRPV4 in colorectal cancer cells. Real time RT-PCR was performed to evaluate TRPV4 mRNA levels in HT-29 and HCT-116 human colorectal cancer cells in comparison with the normal colon CCD-18Co cells. The MTT colorimetric assay was done to assess the effect of a TRPV4 activator GSK1016790A and a TRPV4 inhibitor RN 1734 on the proliferation of human colorectal cancer cells. Real-time RT-PCR analysis revealed that TRPV4 mRNA levels were higher in the normal colon CCD-18Co cells than HT-29 cells. TRPV4 mRNA was undetected in HCT-116 cells. TRPV4 activation by GSK1016790A increased the viability of HT-29 cells while inhibition of TRPV4 using RN 1734 reduced the viability of this cell line. These data suggest that TRPV4 is differentially expressed in human colorectal cancer cells and that pharmacological modulation of TRPV4 exerts differential effects on the proliferation of HT-29 cells. Further functional studies are required to define the possible mechanisms involved.
\end{abstract}

Keywords: TRPV4; Ion channel; Colorectal cancer; Gene expression; Cell viability 


\title{
VANCOMYCIN REDUCED SUSCEPTIBILITY TO METHICILLIN-RESISTANT-STAPHYLOCOCCUS AUREUS
}

\author{
JUNTRIMA, LA-OR; PANOMKET, PAWANA
}

College of Medicine and Public Health, Ubon Ratchathani University. Email: laor.juntrima@gmail.com

\begin{abstract}
Methicillin- resistant Staphylococcus aureus (MRSA) is a major pathogen caused severe infection and increased mortality rate. The prevalence of reports and incidence of methicillin-resistant Staphylococcus aureus (MRSA) vary depending on the sizes of hospitals and the antibiotics used. Vancomycin has long been the drug of choice for the treatment of MRSA infection. Vancomycin-resistant Staphylococcus aureus (VRSA) and vancomycin intermediate S. aureus (VISA) were reported in some hospitals in several countries, including Thailand. This study aimed to determine the susceptibility of vancomycin by minimal inhibitory concentration (MIC) and one point population analysis, population analysis profile and van A detection by PCR. A total of 165 MRSA isolates were collected from patients admitted to Sappasitthiprasong Hospital and Srisakate Hospital between October 2016 to October 2017 and then tested for antimicrobials susceptibility by MIC and spread on brain heart infusion agar supplemented with $6 \mu \mathrm{g} / \mathrm{ml}$ vancomycin. The MRSA were isolated from sputum, pus, and blood. Results showed that vancomycin MIC were 2-32 $\mu \mathrm{g} / \mathrm{ml}$. MIC50 and MIC90 were 4 and $8 \mu \mathrm{g} / \mathrm{ml}$ respectively. There were 101 isolates grown on brain heart infusion agar supplemented with $6 \mu \mathrm{g} / \mathrm{ml}$ vancomycin. Population analysis profile were found heterogeneous vancomycin-intermediate S. aureus (hVISA), vancomycin-intermediate S. aureus (VISA) but not found VRSA. All MRSA had MIC 8-32 $\mu \mathrm{g} / \mathrm{ml}$ were further studied vanA by PCR. There were no vanA detection. This study concluded that MRSA reduced susceptibility to vancomycin. However, vanB, vanC were further subjected identified.
\end{abstract}

Keywords: Methicillin-resistant Staphylococcus aureus (MRSA); Vancomycin; Heterogeneous vancomycin-intermediate S. aureus (hVISA); Vancomycin-intermediate S. aureus (VISA); Vancomycin-resistant S. aureus (VRSA) 


\title{
EVALUATION ON THE QUALITY OF GENOMIC DNA IN BOTH SALIVA AND WHOLE BLOOD AS SOURCE OF DNA AND ITS UTILISATION IN TETRA-ARMS PCR.
}

\author{
HASHIM, HAZWANIE; AZEMI, NUR ASHIKIN
}

International Medical University, Bukit Jalil, 57000 Kuala Lumpur.Email: hazwaniehashim@imu.edu.my

\begin{abstract}
Deoxyribonucleic acid (DNA) that isolated from whole blood is commonly used in epidemiology studies. DNA derived from saliva (SD DNA) offers convenient method for sample collection as compared to DNA derived from whole blood (WB DNA). The purity and concentration of isolated DNA may vary depending on various techniques and methods used. Therefore, we aim to assessed the quality of SD DNA versus WB DNA and further used in pre-optimised genotyping method of tetra-primer amplification refractory mutation system-polymerase chain reaction (T-ARMS-PCR). All DNAs were isolated by using commercial available kit designated for blood and saliva respectively. A total of 204 of human genomic DNA were assessed. The concentration and purity were evaluated by using nanophotometer. The DNAs purity were determined based on the absorbance ratio of A260/280 and A260/230. Our findings demonstrate the mean concentration of WB DNA was significantly higher than SD DNA (59.4 $\pm 32.9 \mu \mathrm{g} / \mathrm{ml}$ vs $39.2 \pm 32.9 \mu \mathrm{g} / \mathrm{ml})$. On the purity assessment, $75.5 \%(\mathrm{n}=154)$ of the samples were within the optimal range of A260/280 ratio from 1.6 to 2 . Of this value, $35.7 \%(n=55)$ and $64.3 \%(n=99)$ were from SD and WB DNAs respectively. Further analysis revealed a decreased intensities of bands amplified by SD DNA compared to WB DNA. Nevertheless, amount of SD DNAs within the range of 40 to $160 \mathrm{ng}$ have shown to produce sufficient intensities bands in T-ARMS-PCR assay. This study highlighted the potential of utilisation of SD DNA in T-ARMS-PCR assay for large scale epidemiological studies.
\end{abstract}

Keywords: DNA source; Saliva; Blood; Genotyping; T-ARMS-PCR 


\title{
EFFECT OF ASTAXANTHIN-RICH XANTHOPHYLLOMYCES DENDRORHOUS EXTRACT ON THE CELL CYCLE OF BREAST CANCER CELLS \\ KHAW SHIN YUAN; CHEW AI LAN
}

Institute for Research in Molecular Medicine (INFORMM), Universiti Sains Malaysia, 11800 USM, Pulau Pinang, Malaysia Email: sychristy91@gmail.com

\begin{abstract}
Understanding cell cycle regulation in cancer study helps in improvement of the cancer therapy as the type and the extent of aggressiveness of particular cancers are determined by specific flaws in the cell cycle regulation. Xanthophyllomyces dendrorhous is a basidiomycetous yeast that is relevant to biotechnology, as it synthesizes astaxanthin as its principal pigment. Astaxanthin is a xanthophyll carotenoid with high antioxidant activity and potential protective effects against carcinogenesis. A astaxanthin-hyperproducing mutant of X. dendrorhous, M34, was obtained in our previous study for the production of astaxanthin-rich Xanthophyllomyces dendrorhous extract (XDE). Due to limited information on the bioactivities of XDE, the present study investigated the effects of XDE on breast cancer subtypes, MCF-7 and MDA-MB-231. Both human breast cancer cell lines were treated with XDE for 24 hours. The cells were then harvested and stained with PI dye for flow cytometry analysis. Flow cytometry results indicated that XDE induced G2/M cell cycle arrest and cellular apoptosis in MCF-7 cancer cells while MDA-MB-231 cells were arrested at S phase. The finding demonstrated that the effects of XDE were differ on breast cancer cells with dissimilar estrogen receptors, providing a basic information for using XDE as a chemopreventive agent for breast cancer.
\end{abstract}

Keywords: Breast cancer cells; Xanthophyllomyces dendrorhous; Astaxanthin; Cell cycle analysis; Estrogen receptor status 


\title{
ULTRASOUND ASSISTED EXTRACTION OF MORINGGA OLEIFERA LEAVES EXTRACT INHIBITS MIGRATION OF HUMAN BREAST CANCER CELL LINES VIA DOWNREGULATION OF MMP-9 \\ NOZLENA AS; KUMARAROOBINI P; KZ KHOR; V LIM; NIK MOHAMED KAMAL NN
}

Integrative Medicine Cluster, Advanced Medical and Dental Institute, SAINS@Bertam, Universiti Sains Malaysia, 13200 Kepala Batas, Pulau Pinang, Malaysia. Email: nozlena@usm.my

\begin{abstract}
Cell migration is a crucial step in cancer metastasis and phytochemicals has been used as an innovative tool in suppressing this process. In current study, anti-migration effects of M.oleifera leaf extract on breast cancer cell line, MCF-7 was evaluated and how the plant extract regulate MMP-9 expression was determined by western blot. M.oleifera ethanol at lower concentration caused significant inhibition in the closure and at higher concentrations which is double $\mathrm{IC}_{50}$ concentration demonstrated almost $100 \%$ inhibition of mcf-7 cells migration. MTT assay was carried out on HUVEC cells and the $\mathrm{IC}_{50}$ concentration was shown to be $125 \mu \mathrm{g} / \mathrm{mL}$. Western blot analysis revealed that M.oleifera ethanol extract significantly (P < 0.05) decreased the expression of molecular effectors for tumor migration, the matrix metalloproteinase-9 protein (MMP-9). Thus, we can conclude that M.oleifera ethanol extract suppressed migration of MCF-7 cell by downregulating MMP-9. Acknowledgement: USM Bridging grant 304/CIPPT/6316056.
\end{abstract}

Keywords: Moringga oleifera, ethanol extract, anti-migration 


\title{
UP-REGULATION OF VIMENTIN PROTEIN EXPRESSION IN TZD SOLUTIONS PRETREATED BONE MARROW-DERIVED MESENCHYMAL STEM CELLS \\ LIM SHERN KWOK; SHIM SIANG YIAN; GAM LAY HARN; KHOO BOON YIN
}

Institute for Research in Molecular Medicine (INFORMM), Universiti Sains Malaysia, 11800 Minden, Penang, Malaysia. Email: shaunlimlim@gmail.com

\begin{abstract}
The ability of bone marrow-derived mesenchymal stem cells (BMSC) to increase the metastatic potential of cancer cells, e.g. MCF-7 (a weakly metastatic breast cancer cell line) is well documented. However, when MCF-7 was co-cultured with BMSC that was pretreated with thiazolidinedione (TZD) solutions, the growth and proliferation of the cancer cells were reduced. Using MALDI-TOF/TOF, ten proteins were identified to have expressed differently after BMSC was pretreated with the TZD solutions. However, the expression of the identified individual protein in the TZD solutions pretreated BMSC remains unclear. Objective: This study aimed to profile the differentially expressed identified proteins in the TZD solutions pretreated BMSC using Western Blotting. Methodology: BMSC was first pretreated with different combinations of TZD solutions for one week before the total proteins of the pretreated BMSC were extracted. The expression levels of the proteins were then evaluated using Western blotting and the relative band intensity of the protein of interest relative to $\beta$-actin in each sample was analysed using Image J. Results: The results showed that the change in the expression level of vimentin was the most significant among the identified proteins, where vimentin showed 1.66-fold change, 2.61-fold change ( $\mathrm{p}<0.05), 1.29$-fold change and 1.77-fold change in TZD1, TZD2, TZD3 and TZD4 solutions pretreated BMSC vs untreated BMSC (control), respectively. Conclusion: The finding indicates that up-regulation of vimentin protein expression in BMSC may play an important role in the growth and proliferation reduction of MCF-7 cells when the pretreated BMSC and the cancer cells were cocultured together.
\end{abstract}

Keywords: Vimentin; Protein expression; BMSC; TZD solution; Stem-and-cancer cell interaction 


\title{
ANTI-CANCER PROPERTY OF RILUZOLE ON OESTROGEN POSITIVE BREAST CANCER CELLS AZAHAR, IRFAN IRSYAD'; SITI NORASIKIN MOHD NAFI²; HASNAN JAAFAR²; CHE HAS, AHMAD TARMIZI ${ }^{3}$; MOKHTAR, NOOR FATMAWATI ${ }^{1}$
}

${ }^{1}$ Institute for Research in Molecular Medicine (INFORMM), Universiti Sains Malaysia Health Campus, 16150 Kubang Kerian, Kelantan, Malaysia. ${ }^{2}$ Department of Pathology, School of Medical Sciences, Universiti Sains Malaysia Health Campus, 16150 Kubang Kerian, Kelantan, Malaysia. ${ }^{3}$ Department of Neurosciences, School of Medical Sciences, Universiti Sains Malaysia Health Campus, 16150 Kubang Kerian, Kelantan, Malaysia. Email: irfanirsyad@ymail.com

\begin{abstract}
Riluzole, a drug synonymous with the treatment of amyotrophic lateral sclerosis (ALS) is now increasingly been identified to exert significant effects on carcinogenesis. The drug was first reported to reduce the tumour size of melanoma patients in a phase 0/I trial. Subsequently, for other type of human cancers, exploring the beneficial effect of riluzole is now highly appreciated. Riluzole, a drug synonymous with the treatment of amyotrophic lateral sclerosis (ALS) is now increasingly been identified to exert significant effects on carcinogenesis. The drug was first reported to reduce the tumour size of melanoma patients in a phase 0/I trial. Subsequently, for other type of human cancers, exploring the beneficial effect of riluzole is now highly appreciated. This study focused on the anti-cancer effect of riluzole on the oestrogen positive human breast cancer cell line, MCF-7 cells whilst tamoxifen was used as control drug. MTT assay was conducted to determine riluzole IC50. Annexin V/PI kit was used to stain phosphatidylserine, a marker of apoptosis (green) and free DNA, necrosis indicator (red), respectively. Stained cells were observed under fluorescence microscopy. Riluzole IC50 was obtained at $27 \mu \mathrm{M}$. Apoptosis induction by riluzole (IC50 - 27 $\mu \mathrm{M}$ ) was confirmed with most cells $(>90 \%$ ) were stained by Annexin V (green) and minimal PI (red), free DNA staining, similar to tamoxifen (IC50 - $30 \mu \mathrm{M}$ ). Our data advocates the anti-cancer effect of riluzole on the oestrogen positive human breast cancer cell line, MCF-7.
\end{abstract}

Keywords: Riluzole; Anti-cancer; Apoptosis; Necrosis; Carcinogenesis 


\title{
INVESTIGATING THE PHENOTYPICAL GROWTH AND INVASION OF THE THREE- DIMENSIONAL (3D) SPHEROIDS GENERATED FROM SIHA, ME180, HT3 AND C33-A CERVICAL CANCER CELL LINES
}

\author{
MUNIANDY,KALAIVANI'; MOHANA KUMARAN,NETHIA²; SHAMSUDDIN,SHAHARUM³; \\ BALAKRISHNAN,VENUGOPAL ${ }^{1}$
}

\begin{abstract}
${ }^{1}$ Institute for Research in Molecular Medicine (INFORMM), Universiti Sains Malaysia, 11800 USM, Pulau Pinang, Malaysia. ${ }^{2}$ School of Biological Sciences, Universiti Sains Malaysia, 11800 USM, Pulau Pinang, Malaysia. ${ }^{3}$ School of Health Sciences, Universiti Sains Malaysia, Health Campus, 16150 Kubang Kerian, Kelantan, MalaysiaEmail: vani_ips@yahoo.com
\end{abstract}

\begin{abstract}
Spheroids are utilised widely in drug sensitivity assays as well as in determining the growth and invasion behaviour pattern of the cancer cells. The model recapitulates tumour microenvironment, concentration gradients and tumour architecture more closely to tumours in vivo. The aim of this study is to elucidate whether the phenotypes displayed by CaSki and HeLa spheroids can be generalized to other HPV 16 or HPV 18 cervical cell lines. The liquid overlay method was employed to generate the spheroids which was then embedded in bovine collagen I matrix. Preliminary data exhibited a remarkable difference in growth and invasion phenotype between CaSki and HeLa spheroids. CaSki spheroids were disintegrated and demonstrated aggressive invasion phenotype into the collagen matrix. In contrast, HeLa spheroids grew and invaded into the collagen matrix more gradually. Disintegration of the spheroids was not observed with the HeLa spheroids. Therefore, growth and invasion phenotypes were compared between two HPV 16 cells (CaSki and SiHa) and between two HPV 18 cells (HeLa and Me180). In contrary to CaSki, SiHa spheroids grew and invaded more gradually into the collagen matrix. The Me180 spheroids grew slower and invaded less aggressively compared to the HeLa spheroids. The C33-A and HT3 non-HPV cells only formed loose aggregates. In conclusion, this study gave an insight into the different growth and invasion phenotypes between different cervical cancer cell lines. It would be a stepping stone to test existing drugs or to design new treatment options for treating cervical cancer according to their HPV infection.
\end{abstract}

Keywords: 3-dimensional Spheroid; Cervical Cancer; HPV 16; HPV 18; non-HPV cervical cancer cells 


\title{
GREATER MRNA EXPRESSION OF ANTIGEN PROCESSING MACHINERY (APM) IN AGGRESSIVE HUMAN BREAST CANCER CELLS
}

\section{MURTADHA, AHMAD HAFIZ; MOKHTAR, NOOR FATMAWATI}

Institute for Research in Molecular Medicine (INFORMM) Universiti Sains Malaysia 16150 Kubang Kerian, Kelantan, Malaysia Email: hafizmurtadha95@gmail.com

\begin{abstract}
LMP2, LMP7, TAP1, TAP2 and MHC-I are genes encoding proteins related to the Antigen Processing Machinery (APM) that functions to process and present peptides to cytotoxic T-lymphocytes (CTL) for immune recognition and response. It was generally believed that expression of APM in human cancers are downregulated. This study was designed to investigate the mRNA expression level of APM in human breast cancer cells with different metastatic potential and compare it to the normal control, human cardiac myocytes. In this study, human breast cancer cell lines, the highly metastatic MDA-MB-231, weakly metastatic, MCF-7 and human cardiac myocytes (as normal control) were used. Total RNA extraction was conducted followed by cDNA synthesis. mRNA expression of LMP2, LMP7, TAP1, TAP2 and MHC-I were measured using real-time PCR (SYBR Green), followed by relative quantification according to $2^{-\Delta C t}$ method. Relative expression of LMP2, LMP7, TAP1, TAP2 and MHC-I were all greatly higher in human cardiac myocytes and the highly metastatic MDA-MB-231 compared to the weakly metastatic MCF-7 cells. Herein, we conclude that the studied APM genes downregulation in weakly metastatic MCF-7 cells follow the general hypothesis by other researchers. However, the studied APM genes upregulation (LMP2, TAP1 and TAP2) in aggressive MDA-MB-231 cells is yet to be fully understood and require further investigation.
\end{abstract}

Keywords: Antigen Processing Machinery; MCF-7; MDA-MB-231; real-time PCR; mRNA expression 


\title{
A SYSTEMATIC REVIEW ON NANO-TIO2 PHYSIOCHEMICAL PROPERTIES TARGETED AS CANCER THERAPEUTIC AGENTS
}

\author{
RABIATUL BASRIA S.M.N. MYDIN ${ }^{1 *}$; AINAA NADHIRAH ZAINON ${ }^{1,2}$; NUR HAZIRAH MOHD AZLAN ${ }^{1}$; SRIMALA \\ SREEKANTAN ${ }^{3}$
}

${ }^{1}$ Oncological and Radiological Sciences Cluster, Advanced Medical and Dental Institute, Universiti Sains Malaysia, 13200 Bertam, Kepala Batas, Pulau Pinang. ${ }^{2}$ Universiti Teknologi MARA Cawangan Perlis Kampus Arau, 02600 Arau, Perlis. ${ }^{3}$ School of Materials and Mineral Resources Engineering, Engineering Campus, Universiti Sains Malaysia, 14300 Nibong Tebal, Pulau Pinang, Malaysia. Email: rabiatulbasria@usm.my

\begin{abstract}
Titanium dioxide nanoparticles (Nano-TiO2) provides promising application as targeted cancer therapeutics. Further, understanding on the ideal physio-chemical properties are crucial for efficient clinical application. This study is conducted based on PRISMA-P protocol. It began with literature searching from selected databases; PubMed, Springer Link, Science Direct and general search engine Google Scholar based on the predetermined Keywords (titanium dioxide nanoparticles, targeted drug delivery, targeted cancer therapy, cancer therapeutic agent, surface modification, physiochemical properties). The search generated 873 manuscripts. We included all pre-clinical and clinical studies, original and inpress articles published within the past 6 years (2013 till 2018). Studies involving usage of besides TiO2 nanoparticles, and those in predatory or blacklisted journals were excluded. Selected studies underwent thorough appraisal yielded 61 articles that answered the research questions and met the inclusion and exclusion criteria. Data from the published studies reported that Nano-TiO2 physicochemical properties which comprised shape, size or diameter, crystal structure, zeta potential, chemical and biological modifications influences the efficiency of desired application. Furthermore, the surface modification of Nano-TiO2 with different ligands could enhanced the treatment efficacy and minimize the adverse effects that current cancer treatment might cause. Results suggested that the delivery routes, biodistribution, clearance and toxicity risk of Nano-TiO2 can be tackled by modulating their physio-chemical properties. Future studies should be directed towards discovering actual potential of Nano-TiO2 for cancer therapeutics which may indeed encourage its clinical application in near future. Acknowledgments: The authors would like to thank Universiti Sains Malaysia (Bridging Research Grant: 304/CIPPT/6316184) for sponsoring this work.
\end{abstract}

Keywords: Titanium Dioxide Nanoparticles; Cancer Therapeutic Agents; Cancer Therapeutics; Physiochemical Properties; Nanotherapeutics, Nanomedicine 


\title{
THE ANTIOXIDATIVE STRESS CAPACITY OF APOCYNIN AND CATALASE ON BIOCHEMICAL, RENAL HAEMODYNAMIC AND HISTOPATHOLOGICAL STUDIES IN L-ARGININE INDUCED HYPOTENSION MODEL: THE ROLE OF OXIDATIVE STRESS
}

\author{
TAN YONG CHIA ${ }^{1 *}$;MUNAVVAR ZUBAID ABDUL SATTAR ${ }^{1}$; NURZALINA BINTI ABDUL KARIM KHAN ${ }^{1}$; ASHFAQ \\ AHMED $^{2}$; MOHAMMED HADI ABDULLAH ${ }^{3}$; HO YOKE MEI ${ }^{1}$; GURJEET KAUR CHATAR SINGH ${ }^{4}$; EDWARD JAMES \\ JOHNS $^{3}$
}

${ }^{1}$ Cardiovascular and Renal Physiology Research Laboratory, School of Pharmaceutical Sciences, University Sains Malaysia. ${ }^{2}$ Department of Pharmacology and Toxicology, School of Medicine, Virginia Commonwealth University, Richmond, United States. ${ }^{3}$ Department of Physiology, University College Cork, Cork, Ireland. ${ }^{4}$ Institute for Molecular Medicine Research, University Sains Malaysia Email: samual_84@hotmail.com

\begin{abstract}
Although the beneficial effect of L-arginine on systemic hemodynamics have been reported in the treatment of cardiovascular diseases. However, its effect on renal function has not been fully elucidated. Treatment of L-arginine often caused hypotension that leads to the occurrence of oxidative stress. This study evaluates the effects of Apocynin-NADPH Oxidase inhibitor and Catalase in L-arginine induced oxidative stress rat's model. Weekly blood pressure, renal functional parameters, renal haemodynamics and histopathology were studied. Wistar-Kyoto rats (48) were randomly distributed into two groups (of four subgroups each) with or without pretreatment with L-arginine (12.5 mg/ml p.o). Each subgroup was treated with normal drinking water, Apocynin $(2.5 \mathrm{mmol} / \mathrm{L} \mathrm{p.o})$ and Catalase (10000 U•kg-1•day-1, i.p. bolus) and Apocynin+Catalase respectively for 14days. Weekly blood and urine samples were collected for biochemical studies. At the end of experiment, animals were subjected to anesthesia with sodium pentobarbital $(60 \mathrm{mg} / \mathrm{kg})$ and renal hemodynamics was studied. All the data were presented in mean \pm SEM and were subjected to Twoway ANOVA analysis followed by Bonferroni post hoc test with significant level at $5 \%$. Administration of L-arginine caused significantly decreased in blood pressure, increased fractional sodium excretion, creatinine clearance and urine flow rate. Plasma malondialdehye and nitric oxide levels have been elevated. In contrary, superoxidase dismutase and total antioxidant capacity has been reduced significantly. Increased of kidney index in L-arginine treated animals has also been observed. Renal cortical blood perfusion and pulse wave velocity was also decreased significantly. No renal tissue damage has been observed in histopathological studies (All $\mathrm{P}<0.05)$. Apocynin and Catalase administration normalized the above stated parameters. As a conclusion, long term administration of L-arginine may lead to dysfunctions in renal functional parameters and low blood pressure and thus the occurrence of oxidative stress. However, we noticed that Apocynin and catalase administration normalized the abnormal renal functional parameters and blood pressure and thus can be considered as a potential antioxidant for future therapeutic options.
\end{abstract}

Keywords: Apocynin; Catalase; L-arginine; Hypotension; Renal Hemodynamics. 